IZA DP No. 5089

The Opt-Out Revolution: A Descriptive Analysis

Heather Antecol

July 2010 


\title{
The Opt-Out Revolution: A Descriptive Analysis
}

\author{
Heather Antecol \\ Claremont McKenna College \\ and IZA
}
Discussion Paper No. 5089
July 2010

IZA

P.O. Box 7240

53072 Bonn

Germany

Phone: +49-228-3894-0

Fax: +49-228-3894-180

E-mail: iza@iza.org

Any opinions expressed here are those of the author(s) and not those of IZA. Research published in this series may include views on policy, but the institute itself takes no institutional policy positions.

The Institute for the Study of Labor (IZA) in Bonn is a local and virtual international research center and a place of communication between science, politics and business. IZA is an independent nonprofit organization supported by Deutsche Post Foundation. The center is associated with the University of Bonn and offers a stimulating research environment through its international network, workshops and conferences, data service, project support, research visits and doctoral program. IZA engages in (i) original and internationally competitive research in all fields of labor economics, (ii) development of policy concepts, and (iii) dissemination of research results and concepts to the interested public.

IZA Discussion Papers often represent preliminary work and are circulated to encourage discussion. Citation of such a paper should account for its provisional character. A revised version may be available directly from the author. 
IZA Discussion Paper No. 5089

July 2010

\section{ABSTRACT}

\section{The Opt-Out Revolution: A Descriptive Analysis}

Using data from the 1980, 1990, and 2000 U.S. Census, I find little support for the opt-out revolution - highly educated women, relative to their less educated counterparts, are exiting the labor force to care for their families at higher rates today than in earlier time periods - if one focuses solely on the decision to work a positive number of hours irrespective of marital status or race. If one, however, focuses on both the decision to work a positive number of hours as well as the decision to adjust annual hours of work (conditional on working), I find some evidence of the opt-out revolution, particularly among white college educated married women in male dominated occupations.

JEL Classification: J13, J15, J16, J22

Keywords: opting out, female labor supply, extensive/intensive margin, race/ethnicity

Corresponding author:

Heather Antecol

Robert Day School of Economics and Finance

Claremont McKenna College

500 E. Ninth Street

Claremont, CA 91711

USA

E-mail: hantecol@cmc.edu 


\section{Introduction}

A number of recent studies have attempted to find evidence to support the opt-out revolution-highly educated women, relative to their less educated counterparts, are exiting the labor force to care for their families at higher rates today than in earlier time periods-which was first sensationalized by Lisa Belkin in a 2003 New York Times article. ${ }^{1}$ The preponderance of these studies focus on the employment side of opting-out (i.e., conditional on having children women exit the labor market $)^{2}$ and generally conclude that there is no evidence to support the popular press' notion of an opt-out revolution, that is, the child penalty is not found to be higher for highly educated women compared to less educated women in recent years (see for example, Boushey 2005, Goldin 2006, Vere 2007, Cohany and Sok 2007, Fortin 2008, and Percheski 2008)..$^{3}$

What can account for the discrepancy in the press' accounts of the opt-out revolution and the studies of the employment side of the opt-out revolution (henceforth referred to as the opt-out literature)? One possibility is the opt-out literature tends to focus on the child penalty unadjusted for demographic characteristics, such as, marital status and race/ethnicity (henceforth referred to

\footnotetext{
${ }^{1}$ Many other media reports followed (see for example, Wallis 2004, Story 2005, and Trunk 2005).

${ }^{2}$ Several studies examine the fertility side of opting out. The results are mixed; Vere (2007) and Shang and Weinberg (2009) find increased fertility among college educated women while Percheski (2008) finds no change in fertility among professional women. Others have examined the impact of opting-out on labor market outcomes among alumni from top-ranked colleges. Goldin and Katz (2008) find no evidence of the opt-out revolution among Harvard University alumnae but do find that opting out impacts earnings, although differentially by occupation. Herr and Wolfram (2009) find that alumnae from Harvard University are less likely to stay attached to the labor market if their workplace lacks family friendly policies. Bertrand, Goldin, and Katz (2009) find that the gender wage gap among MBA graduates from the University of Chicago's Booth School of Business can largely be explained by career interruptions from childbirth. Several studies also seek to understand why highly educated women are exiting the labor market and what the associated costs of exiting may be (see for example, Stone and Lovejoy 2004, Hewlett et al. 2005, Williams et al. 2006, Hewlett 2007, and Stone 2008); these studies tend to be more qualitative in nature.

${ }^{3}$ The one exception is Vere (2007) who does find evidence that highly educated women with children are exiting the labor market at higher rates than their less educated counterparts. However, he only focuses on women 27 years of age which is very young for childbearing, particularly in later cohorts for highly educated women.
} 
as race). ${ }^{4}$ The labor supply decisions of prime-aged women (henceforth referred to as women) with children who are not married are likely to be very different than those of their married women counterparts, particularly at the top of the education distribution, as these women are likely married to men who are also highly educated and have high earning power, affording them the ability to exit the labor market when they have children (see for example, Williams et al. 2006). ${ }^{5}$ Indeed highly educated married women tend to be the focus of the media accounts (Williams et al. 2006). In addition, in 2000 marriage rates among women are higher at the top of the education distribution than at the bottom of the education distribution; this is in stark contrast to 1980 where highly educated women are generally less likely to get married than their less educated counterparts. ${ }^{6}$ Marriage rates have fallen over time as well (see Table 1). Thus by combining married and non-married women, one may be underestimating the child penalty, particularly in recent years.

Similarly, the labor supply decisions of non-Hispanic white (henceforth referred to as white) women with children are likely to be very different than those of their non-white counterparts. The media attention is generally more focused on white affluent women in white collar jobs (Williams et al. 2006). Furthermore, white women are generally more attached to the

\footnotetext{
${ }^{4}$ Boushey (2005) does allow for intercept effects of race/ethnicity and marital status when estimating the effect of children on women's labor force attachment but does not allow for slope effects (i.e., she does not interact marital status or race/ethnicity with children). Cohany and Sok (2007) do report labor force participation by race, however they only do so for married women with infants. While Fortin (2008) estimates the effect of children on women's labor force participation separately by marital status and education, she only stratifies by two education categories: less than college and college graduates. Fortin (2008) also analyzes the effect of children on black women's labor force participation, however, she does not allow for differential effects of children by education or marital status for this group of women. Another demographic characteristic is immigrant status. Results that focus solely on nonimmigrants are generally similar and available upon request.

${ }^{5}$ Cha (2009) finds that professional women with children, married to professional men, were substantially more likely to exit the labor market if their partner worked extreme hours ( $>60$ hours) relative to their childless counterparts whose partners did not work extreme hours.

${ }^{6}$ The marriage rates for women aged 25-44 in 1980 are 69\% (less than high school), 76\% (high school), 72\% (some college) and 69\% (college). The marriage rates for women aged 25-44 in 1990 are 58\% (less than high school), $68 \%$ (high school) , 66\% (some college), and 66\% (college). The marriage rates for women aged 25-44 in 2000 are 57\% (less than high school), 63\% (high school) , 63\% (some college), and 66\% (college).
} 
labor market, are more likely to have a college education, more likely to be married, and are less likely to have children, and if they do have kids, they have fewer of them, relative to their nonwhite counterparts (see Table 1). Moreover, racial differences in educational attainment have become more pronounced over time. All of these racial differences suggest that the child penalty may differ substantially by race, and these differences may shed light on the discrepancies between the results presented in the media and the opt-out literature.

Another possibility is the opt-out literature generally focuses on one aspect of female labor supply, the decision to work a positive number of hours (i.e., the extensive margin), as opposed to conditional on participating in the labor market, the decision to adjust annual hours of work (i.e., the intensive margin). ${ }^{7}$ I argue focusing on both margins may be important because women, particularly highly educated women, may not be choosing to exit the labor market entirely, but may be opting for reduced hours of work. There is support for this in the qualitative literature on opting out (see for example, Hewlett et al. 2005, Hewlett 2007, and Stone 2008), that is, highly educated women are seeking alternative occupations which are less demanding, afford them more flexibility, and require a reduced time commitment. Moreover, Belkin (2003) recognized this possibility in her New York Times Magazine article. This then suggests that defining opting out simply on a woman's decision to exit the labor market may be masking some of the employment aspect of the opt-out revolution.

A third possibility is defining highly educated women simply as college educated may obscure the opt-out phenomenon. It may be that it is college educated women in specific managerial/professional occupations, particularly male dominated occupations (e.g., architects, engineers, lawyers, and physicians), that are more likely to opt out of the labor market in terms

\footnotetext{
${ }^{7}$ Percheski (2008) does consider alternative measures of labor supply (full-time year round employment and works $50+$ hours per week) but does not try to disentangle the relative roles of extensive and intensive margin.
} 
of both the extensive and intensive margin. ${ }^{8}$ On the one hand, women in these occupations may be more inclined to exit the labor market entirely because these occupations offer the least amount of job flexibility (see Stone 2008). On the other hand, women in these types of occupations likely worked extreme hours (e.g., 60+ hours/week) prior to having their child/children, and may be able to adjust their hours down to accommodate their new family roles. In addition, it is this group of women that the media tends to focus on (see Williams et al., 2006).

In this paper, I show that, as in the existing opt-out literature, there is little evidence to support the opt-out revolution if one focuses solely on the extensive margin. Specifically, using the 1980, 1990, and 2000 U.S. Census, I find that the child penalty for women fell substantially between 1980 and 1990 irrespective of one's level of education. Moreover, the child penalty for this group did not increase in recent years; in fact the child penalty continued to fall (although to a lesser degree) between 1990 and 2000 for all education categories except for the college educated category where the child penalty in 2000 remained roughly equal to the child penalty in 1990. The same patterns generally hold for college educated married women irrespective of race, that is, the child penalty did not increase between 1990 and 2000.

As predicted, I find that the overall child penalty in female labor supply is higher if one focuses on both the extensive and intensive margin, suggesting the importance of accounting for both margins. Despite this, the overall child penalty in female labor supply for college educated married women does not rise, as predicted by the opt-out revolution, but falls in recent years. While this holds true for white and Hispanic college educated married women, the reverse is true

\footnotetext{
${ }^{8}$ While Percheski (2008) does examine women in managerial/professional occupations, as well as the subset of traditionally male and female dominated occupations within this occupational category, she does not examine detailed occupations in managerial/professional occupations, traditionally male occupations, or traditionally female occupations. Focusing on aggregate categories may mask the opt-out phenomenon as there are different degrees of flexibility and the incidence of extreme hours in the detailed occupations within each occupation category.
} 
for their non-Hispanic black (henceforth referred to as black) and Asian counterparts. Strikingly, I find that the child penalty does increase between 1990 and 2000 for white college educated married women who are in male dominated occupations whereas for white college educated married women in female dominated and mixed occupations the child penalty decreases between 1990 and 2000. Taken together, these patterns suggest that there is some support for the opt-out revolution particularly among the group of women that the media tends to focus on, that is, white college educated married women who are in male dominated occupations.

The remainder of the paper is as follows. The data is discussed in Section 2. Section 3 examines labor force attachment by marital status, race, year and level of education. Section 4 presents the results for the child penalty decomposition. Section 5 presents an in depth analysis for white college educated married women. The conclusions are presented in Section 6.

\section{Data}

I use data from the Integrated Public Use Microdata Series (IPUMS) 5\% sample of the 1980, 1990, and 2000 United States Census. This data is ideal for my purposes because it has detailed information on family characteristics (marital status and presence of children), labor market characteristics (usual hours worked per week, weeks worked in the past calendar year, and occupation), and demographic characteristics (age and education), as well as having large samples of women within educational, racial/ethnic, and occupational categories. ${ }^{9}$

\footnotetext{
${ }^{9}$ Ideally, one would supplement the Census data with data from the Current Population Survey (CPS) to get information on the years between the censuses, as well as information beyond 2000. Unfortunately, due to small sample sizes this is not possible for all educational, racial/ethnic, and occupational categories. Despite this shortcoming, I am able to use the CPS to investigate the opt-out phenomenon for Non-Hispanic white college educated married women. This analysis is presented in detail in Section 5.
} 
I restrict the sample to women between the ages of 25-44 who are employed in the civilian labor force and do not have allocated values on any of the variables of interest. ${ }^{10}$ I focus on 25-44 year olds to ensure that women have completed their formal education, as well as allowing them sufficient time to begin forming their families. I only focus on the civilian labor force as the armed forces labor force is very different and likely attracts women with different preferences for work and family.

I consider four racial groups, white, black, Hispanic, and Asian. These are constructed as indicator variables equal to one if the respondent is of that particular race, and zero otherwise. ${ }^{11}$ Table 1 presents summary statistics by race and year. The proportion of the female population that is white (non-white) decreased (increased) over the time period, with the biggest increase realized by Hispanics. Whites (Hispanics) accounted for 80.7 (6.1), 76.5 (8.1), and 70.7 (10.9) percent of the female population in 1980, 1990, and 2000, respectively.

I consider three measures of labor supply. The first measure of labor supply considered is unconditional annual hours of work. This is defined as usual hours per week times weeks worked in the past calendar year. It therefore includes women who are not working as by construction it includes zero values. I also consider conditional annual hours of work measured as annual hours of work conditional on working positive annual hours of work. Finally, I consider labor force attachment (LFA) which is defined to equal one if a respondent worked positive annual hours, and zero otherwise. ${ }^{12}$ By focusing on these three measures, I am able to examine both the intensive and extensive margins (discussed in detail below).

\footnotetext{
${ }^{10}$ Specifically, I drop an individual if they have an allocated value for age, sex, race, Hispanic, education, usual hours of work, weeks worked per year, employment status, marital status, and relationship to household head.

${ }^{11}$ In order to construct these variables I rely on two IPUMS variables: race (RACED) and Hispanic origin (HISPAND).

${ }^{12}$ Alternatively I could have used labor force participation (LFP) which equals one if a respondent was employed or actively seeking employment in the reference week, and zero otherwise. While this is the measure generally considered in the opt-out literature, for my purposes labor force attachment (LFA) is needed to determine the
} 
Women were more attached to the labor market in 2000 relative to 1980 irrespective of the labor supply measure considered, although the biggest increase in labor supply occurred between 1980 and 1990. For example, LFA rates in 1980, 1990, and 2000 are 68.3, 77.2, and 78.7 percent, respectively. The same general pattern holds for all races, although it is more pronounced for white women. Focusing again on LFA, white women's LFA rates increased 12.3 percentage points between 1980 and 2000 while black, Hispanic, and Asian women's LFA rates increased by 9.8, 8.1, and 2.3 percentage points, respectively, in this time period.

To determine the child penalty, information on presence of children in the household is needed. I use the family relationship variables constructed in the IPUMS data to ascertain the presence of children. The first indicator variable is constructed based on the number of own children (biological, adopted, or step children) in the household (NCHILD). Specifically, I create an indicator variable equal to 1 if there are no own children in the household, and zero otherwise. A second indicator variable is constructed based on the number of own children under age 5 in the household (NCHLT5). Specifically, I create an indicator variable equal to 1 if there are any own children less than 5 in the household, and zero otherwise. For prime-aged women, own children in the household is a relatively good approximation for fertility (see Rindfuss 1976). The number of own children decreased from 1.668 in 1980, to 1.399 in 1990, and 1.386 in 2000 while the proportion of women who had no children increased from 25.6 percent, to 31.6 percent in 1990, and 33.0 percent in 2000. The proportion of women having children less than five is relatively stable between 1980 and 2000; 27.6, 27.2, and 26.5 percent in 1980, 1990, and 2000, respectively. While the levels are different across racial groups (e.g.,

relative roles of the intensive and extensive margins of labor supply. Results based on LFP are very similar to results based on LFA and are available upon request. 
non-whites have more children than their white counterparts), the overall patterns tend to hold for all racial groups.

I also create a marital status indicator variable equal to one for married, spouse present, and zero otherwise. Marriage rates have fallen over time from 72.9 percent in 1980, to 65.6 percent in 1990, and to 63.4 percent in 2000. Blacks experienced the largest decline in marriage rates between 1980 and 2000 (11.8 percentage points) followed by whites (8.6 percentage points), Asians (6.8 percentage points), and Hispanics (6.8 percentage points).

In addition, I consider 4 educational categories, less than high school (grade 11 or less), high school (grade 12), some college (1-3 years of college), and college (4+ years of college). ${ }^{13}$ These are constructed as indicator variables equal to one if the respondent has attained that particular level of education, and zero otherwise. Women have acquired more education between 1980 and 2000; 18.0 (18.5), 10.9 (23.7), and 8.8 (29.6) percent of women had a less than high school (college) degree in 1980, 1990, and 2000, respectively. The increase in college attendance between 1980 and 2000 is highest for Asians (37.2 to 51.5 percent), followed by whites (19.9 to 32.7 percent), blacks (11.1 to 19.1 percent), and Hispanics (7.4 to 13.7 percent).

Finally, I examine detailed occupations that fall into 3 occupational categories within the managerial/professional occupations: male dominated (roughly 70 percent male or higher in 1980, 1990 and 2000), female dominated (roughly 30 percent male or lower in 1980, 1990 and 2000), and mixed occupations (roughly between 40 and 60 percent male in 1980, 1990 and 2000). These categories are constructed based on the "occupation, 1990 basis" (OCC1990)

\footnotetext{
${ }^{13}$ These categories are constructed based on the educational attainment recode variable (EDUREC) in the IPUMS data which combines two separate IPUMS variables HIGRADE and EDUC99. The former is available from 1940 to 1980 and the latter is available from 1990-2000. The recoded variable was constructed to allow for analysis across the years. The main differences are high school based on EDUC99 is $12^{\text {th }}$ grade no diploma and high school diploma or GED, some college based on EDUC99 is some college no degree, occupational associate degree, and academic associate degree, and college based EDUC99 is bachelor's degree, master's degree, professional degree and doctorate degree.
} 
variable in the IPUMS data for individuals between the ages of 18 to 64 . An ideal feature of the IPUMS occupation question is that it applies to individuals who had worked within the previous five years which allows one to examine both the extensive margin and intensive margin. Moreover, the 5 year time frame coincides with the presence of young children, i.e., children less than 5 years of age. See Appendix Table 2 for a detailed list of occupations by year that fall under each occupation category, as well as the percent male within each detailed occupation category.

Unfortunately due to small sample sizes (particularly in male dominated occupations), I am only able to consider a subset of detailed occupations within each occupation type (see Appendix Table 2 for the sample size of white college educated married women by occupation, year, and presence of children). ${ }^{14}$ The detailed male dominated occupations considered are architects, electrical engineers, physicians, lawyers, clergy/religious workers. The detailed female dominated occupations considered are registered nurses, dieticians/nutritionists, occupational therapists, primary school teachers, and librarians. The mixed occupations considered are human resources and labor relations manager (henceforth referred to as human resources), accountants and auditors, secondary school teachers, economists and market researchers (henceforth referred to as economists), and editors/reporters.

\section{Labor Force Attachment (LFA) by Year, Education, and Race}

Following the opt-out literature, I first focus on the extensive margin (i.e., the decision to work a positive number of hours). Figure 1 presents the labor force attachment (LFA) rates for all women aged 25-44 by presence of young children, year, and education. Figure 1 also presents the child penalty measured as:

\footnotetext{
${ }^{14}$ An occupation is considered if there are at least 25 women without kids/with kids less than 5 in each year.
} 


$$
\frac{\overline{L F A}_{N K}-\overline{L F A}_{K L T 5}}{\overline{L F A}_{N K}}
$$

where $\overline{L F A}$ is mean labor force attachment and NK and KLT5 denote women without children and women with young children, respectively. ${ }^{15}$

There are several noteworthy patterns. First, LFA of women with young children has increased over time irrespective of education category, although the increase is more pronounced between 1980 and 1990 than between 1990 and 2000. For example, the LFA rate for women with young children increased from 52.0 in 1980 to 65.0 percent in 1990 and 68.0 percent in 2000. Perhaps surprisingly, the same is not true for women without children. For less educated (high school or below) the LFA of childless women decreased over time (e.g., 56.5, 54.8 and 52.4 percent in 1980, 1990, and 2000 for women with less than high school) while for more educated (some college and above) the LFA of childless women remained relatively flat between 1980 and 2000 (e.g., 94.9, 95.6 and 94.4 percent in 1980, 1990, and 2000 for women with college).

Second, LFA is higher among women with higher levels of education relative to their less educated counterparts irrespective of year or presence of children. Focusing on 2000, it can be seen that the LFA rate for childless women with less than high school is 52.4 percent while their high school, some college, and college counterparts have LFA rates of 77.7, 89.5, and 94.4 percent, respectively.

Third, childless women have higher LFA rates than women with young children. This is again true regardless of the education category or year considered. For example, in 1990 the LFA rate for childless women is 77.6 percent while the LFA rate for women with young children LFA rate is 64.5 percent.

\footnotetext{
${ }^{15}$ Percheski (2008) measures the child penalty analogously.
} 
Fourth, there is no clear pattern by education in the child penalty in a given year. In 1980 and 1990 the child penalty rises (falls) as one acquires more education at the bottom (top) of the education distribution while in 2000 the child penalty generally rises with education. For example, in 1980 (2000) the child penalty for women with less than high school, high school, some college, and college is 31.7 (16.6), 40.7 (18.9), 37.5 (18.9), and 34.2 (21.8), respectively. There is, however, a clear pattern in the child penalty over time in a given education category. Specifically, the child penalty fell between 1980 and 1990 for all education groups, while between 1990 and 2000 it fell (although a much smaller decline than in the previous time period) for all education groups except college educated women where the penalty remained relatively constant. For instance, the child penalty for high school educated women went from 40.6 percent in 1980, to 26.6 percent in 1990, to 18.9 percent in 2000 while for college educated women the child penalty went from 34.2 percent in 1980 , to 22.2 percent in 1990 , to 21.8 percent in 2000. Taken together, these results provide little support for the media accounts of the opt-out revolution. ${ }^{16}$

Figure 1 combines all women irrespective of marital status. As previously discussed, the media tends to focus on highly educated married women who may have the luxury to opt-out of the labor market because they tend to be married to highly educated men with high earning potential (see for example, Williams et al. 2006). Moreover, marriage rates for college educated women in 2000 are higher than those of their less educated counterparts; this was not true in 1980. Marriage rates have fallen over time as well (see Table 1), although less so for college educated women. By combining married women with non-married women, one may be underestimating the child penalty, particularly in recent years. Thus, for the remainder of the

\footnotetext{
${ }^{16}$ The same patterns are found if one examines the child penalty by education, age, and year, as well as by education, age, and birth cohort (results available upon request). This is discussed in greater detail for a subset of the sample in Section 5.
} 
analysis I focus on married women. Figure 2 presents the LFA rates and the child penalty for married women by presence of young children, education, and year. While there is evidence that the child penalty is underestimated in recent years (particularly at the bottom of the education distribution), it remains the case that the child penalty did not rise between 1990 and 2000 for college educated women.

Allowing for differential effects by race may help shed light on the discrepancy between the media accounts of the-opt out revolution and the results presented to this point. Specifically, it is unlikely that the child penalty will be the same by race given there are substantial racial differences in labor force attachment, educational attainment, marital status, and presence of children (see Table 1). Figures 3, 4, 5, and 6 present the LFA rates and the child penalty for married women by presence of young children, education, and year for whites, blacks, Hispanics, and Asians, respectively.

Not surprisingly, the results for married white women (Figure 3) mirror those presented for all married women (Figure 2) given white women make up such a large share of the total population. The patterns for non-white married women differ somewhat from their white counterparts. In particular, the child penalty generally falls as non-whites acquire more education irrespective of year. ${ }^{17}$ The child penalty is generally smaller in magnitude for nonwhites, and this is particularly true for married black women. ${ }^{18}$ For example, the child penalty for white married women in 2000 is $29,26,24$, and 24 percent for less than high school, high school, some college, and college, respectively (see Figure 3) while the child penalty for black married women in 2000 is 1, 3, 7, and 7 percent for less than high school, high school, some

\footnotetext{
${ }^{17}$ The main exception is for Black married college educated women in 2000 who face a higher child penalty than their less educated counterparts.

${ }^{18}$ The main exception is for Asian married women with less than high school in 1990 who face a child penalty of 42 percent (see Figure 6) while their white married counterparts face a child penalty of 28 percent (see Figure 3).
} 
college, and college, respectively (see Figure 4). What is true for all racial groups, however, is that the child penalty for college educated women did not increase between 1990 and 2000.

The LFA patterns revealed in Figures 1 through 6 are consistent with the evidence from the opt-out literature (see Boushey 2005, Cohany and Sok 2007, and Percheski 2008) and suggest that the opt-out revolution, as sensationalized by Lisa Belkin in a 2003 New York Times article, is not generally supported in the data. In other words, the child penalty did not increase in recent year for college educated women, nor did college educated women face a higher child penalty relative to their less educated counterparts within a given year, irrespective of race or marital status. ${ }^{19}$

This conclusion however is based on the extensive margin (i.e., the decision to work a positive number of hours), and does not consider the intensive margin (i.e., conditional on participating in the labor market, the decision to adjust annual hours of work). I argue this is important because women, particularly highly educated women, may not be choosing to exit the labor market entirely, but may be opting for reduced hours of work. This then suggests that defining opting out as simply labor market attachment may be masking some of the "opt-out revolution”. The remainder of the paper examines the child penalty based on both the extensive and intensive margin.

\section{Decomposition of the Overall Child Penalty by Year, Education, and Race}

To formally analyze both the extensive and intensive margin, I first note that mean unconditional annual hours is equal to conditional annual hours times LFA. Given this, the child

\footnotetext{
${ }^{19}$ The main exception is for black college educated married women in 2000 who face a child penalty of 7 percent, while black married women with less than high school, high school, and some college face a child penalty of 1, 3 , and 7 percent, respectively (see Figure 4).
} 
penalty in unconditional annual hours (henceforth referred to as the overall child penalty) can be written as

$$
\frac{\overline{U A H}_{N K}^{M}-\overline{U A H}_{K L T 5}^{M}}{\overline{U A H}_{N K}^{M}}=\frac{\overline{C A H}_{N K}^{M} * \overline{L F A}_{N K}^{M}-\overline{C A H}_{K L T 5}^{M} * \overline{L F A}_{K L T 5}^{M}}{\overline{U A H}_{N K}^{M}}
$$

where $\overline{U A H}$ is mean unconditional annual hours, $\overline{C A H}$ is mean conditional annual hours, $\overline{L F A}$ is mean labor force attachment, and M, NK, and KLT5 denote married, women without children, and women with young children, respectively. I now add and subtract from the numerator of the right hand side (RHS) of equation (2) the counterfactual mean unconditional annual hours for married women without children if they had the mean labor force attachment of married women with young children $\left(\overline{\mathrm{CAH}}_{N K}^{M} * \overline{L F A}_{K L T 5}^{M}\right)$ :

$$
\begin{aligned}
& \frac{\overline{U A H}_{N K}^{M}-\overline{U A H}_{K L T 5}^{M}}{\overline{U A H}_{N K}^{M}}= \\
& \frac{\overline{C A H}_{N K}^{M} * \overline{L A}_{N K}^{M}-\overline{C A H}_{N K}^{M} * \overline{L A}_{K L T 5}^{M}+\overline{C A H}_{N K}^{M} * \overline{L A}_{K L T 5}^{M}-\overline{C A H}_{K L T 5}^{M} * \overline{L A}_{K L T 5}^{M}}{\overline{U A H}_{N K}^{M}}
\end{aligned}
$$

Collecting terms:

$$
\frac{\overline{U A H}_{N K}^{M}-\overline{U A H}_{K L T 5}^{M}}{\overline{U A H}_{N K}^{M}}=\frac{\left(\overline{L A}_{N K}^{M}-\overline{L A}_{K L T 5}^{M}\right) * \overline{C A H}_{N K}^{M}}{\overline{U A H}_{N K}^{M}}+\frac{\left(\overline{C A H}_{N K}^{M}-\overline{C A H}_{K L T 5}^{M}\right) * \overline{L A}_{K L T 5}^{M}}{\overline{U A H}_{N K}^{M}}
$$

The first term on the RHS of equation (4) represents the portion of the overall child penalty due to the extensive margin and the second term represents the portion of the overall child penalty due to the intensive margin. ${ }^{20}$ Dividing each term on the RHS of equation (4) by the overall

\footnotetext{
${ }^{20}$ Instead, I could have added and subtracted from equation (3) the counterfactual mean unconditional annual hours for married women without children if they had the mean conditional annual hours of married women with young children ( $\overline{C A H}_{K L T 5}^{M} * \overline{L A}_{N K}^{M}$ ). This adjusts the intensive margin, as opposed to the extensive margin (as is done in equation 3). While this yields a slightly larger role for the intensive margin, the overall patterns are the same (results available upon request).
} 
child penalty (and multiplying by 100) gives the percent explained by the extensive and intensive margin, respectively. ${ }^{21}$

Before focusing on the decomposition results, it is worthwhile to discuss the patterns in female labor supply based on unconditional annual hours, as well as the patterns in the overall child penalty. Unconditional annual hours have generally increased for married women irrespective of presence of children or level of education (see Figure 7). ${ }^{22}$ For example, college educated childless women worked 1624 unconditional annual hours in 1980 compared to 1835 and 1887 unconditional annual hours in 1990 and 2000, respectively. While this rise in unconditional annual hours holds for white married women (see Figure 8), it does not for their non-white counterparts (see Figures 9-11). For example, black married childless women with lower levels of education (high school or less) experience a fall in unconditional annual hours between 1990 and 2000 (see Figure 9). In addition, the overall child penalty is higher than the child penalty in LFA irrespective of race, education level, and year, suggesting the importance of accounting for both the extensive and intensive margin. For example, for college educated married women in 2000 the overall child penalty is 38.6 (see Figure 7) while the child penalty in LFA is 21.8 (see Figure 1).

Turning to the decomposition results (see Table 2), I find the intensive margin explains a larger share of the overall child penalty as married women acquire more education irrespective of the year considered. For example, in 2000 the intensive margin explains 26.6, 33.9, 40.9, and 42.8 percent of the overall child penalty for less than high school, high school, some college, and college, respectively (see column 3). Interestingly, the portion of the overall child penalty

\footnotetext{
${ }^{21}$ Antecol and Steinberger (2009) use a similar technique to examine differences in labor supply between married women and partnered lesbian women.

${ }^{22}$ The main exception is for married women with young children who have less than high school between 1990 and 2000 where unconditional annual hours marginally fell.
} 
explained by the extensive margin decreased between 1980 and 1990 and increased between 1990 and 2000 for all education categories, although it is more pronounced for college educated women. This suggests that married women, particularly college educated married women, in recent years are reverting back to adjusting their labor supply on the extensive margin as opposed to the intensive margin. This is noteworthy in its own right as it may reflect the fact that college educated married women may have less of an opportunity to adjust their hours of work any further due to workplace hour constraints. If they require more flexibility than their workplace can provide, then they may feel they are left with no choice but to exit the labor market. This phenomenon has been documented in the qualitative literature (see for example, Stone 2008).

The overall patterns hide some important racial differences. While similar results are found for white and Hispanic married women, the same is not true for black and Asian married women. For black married women, the intensive margin plays the biggest role for college educated women relative to their less educated counterparts in 1980 and 1990 (see columns 7 and 8) while in 2000 it is least important for college educated women relative to their less educated counterparts (see column 9). This is largely explained by the fact that the LFA rates of black married women with less than high school in 2000 were virtually identical, not because black married women with young children substantially increased their LFA between 1990 and 2000 in this education category but because childless black married women with less than high school substantially reduced their LFA during this time period (see Figure 4). There are no clear patterns in the importance of the intensive margin by level of education for Asian married 
women. ${ }^{23}$ For black (Asian) married college educated women, on the other hand, the relative role of the extensive margin remained roughly the same (decreased) between 1990 and 2000.

Despite the fact that the aforementioned patterns illustrate the importance of accounting for both the extensive and intensive margins, as with the child penalty in LFA, the overall child penalty does not increase in recent years for married college educated women (see Figure 7). This, however, masks important racial differences. Specifically, the child penalty for black (Asian) college educated married women increases by 1.5 (2.3) percentage points between 1990 and 2000 (see Figure 9 (11)). For white and Hispanic college educated married women, the child penalty falls by 3.6 and 3.1 percentage points, respectively, between 1990 and 2000 (see Figures 8 and 10, respectively). These patterns continue to suggest limited evidence in support of the opt-out revolution, particularly for white college educated married women who tend to be the focus of the media. This may be driven by the fact that college education is too coarse of a definition for this group. Thus the remainder of the paper presents an in depth examination of white college educated married women.

\section{A Further Investigation of Non-Hispanic White College Educated Married Women}

The opt-out phenomenon among non-Hispanic white (henceforth referred to as white) college educated married women may be obscured for a number of reasons. First, it may be that limiting the analysis to 2000 is too early a time period in which one could detect the opt-out phenomenon, which was not brought to the public's attention until Belkin's 2003 New York Times article. Second, it may be that the propensity to opt-out of the labor market varies by age

\footnotetext{
${ }^{23}$ According to Table 2 (columns 13-15), the relative importance of the intensive margin in 1980 is higher for Asian married women with some college, followed by less than high school, college, and high school while in 1990 (2000) the relative importance of the intensive margin is higher for Asian married women with some college (less than high school) followed by high school (college), college (some college), and less than high school (high school).
} 
for college educated women as there may be large differences in the work behavior of young women relative to older women due to, for example, a change in preferences towards work and family (i.e., culture). Finally, it may also be that college educated women across occupation categories have different propensities to opt-out of the labor market as the opportunities for work-place flexibility vary by occupation. Each of these possibilities is examined in turn.

Table 3 presents the decomposition of the overall child penalty for white college educated married women by year: 1980, 1981-1983, 1984-1986, 1987-1989, 1990, 1991-1993, 1994-1996, 1997-1999, 2000, 2001-2003, 2004-2006, 2007-2009. The data for 1980, 1990, and 2000 continue to be based on the U.S. census data, while the data for the intervening years are from Integrated Public Use Microdata Series (IPUMS) March Current Population Survey (CPS) samples. These data are ideal for these purposes because IPUMS constructs the variables to align with those in the census data, however, the CPS sample sizes are small. ${ }^{24}$ Given the small sample sizes, I pool over three year periods in the CPS. Interestingly, it can be seen that, if anything, evidence of the opt-out phenomenon actually occurs between the latter half of the 1990s and the early 2000s, as opposed to the mid- to the late- 2000 s. $^{25}$ Specifically, the overall child penalty falls continuously from 60.3 in 1980 to 40.2 in 1997-1999, increases to 41.6 in 2000 and 42.2 in 2001-2003, ${ }^{26}$ then falls thereafter (39.9 in 2004-2006 and 38.3 in 2007-2009). ${ }^{27}$

\footnotetext{
${ }^{24}$ Ideally one would use this data throughout the analysis, however due to small sample sizes this is not possible for all educational, racial/ethnic, and occupational categories.

${ }^{25}$ Interestingly, a similar pattern is found if one solely examines the extensive margin. In particular, the child penalty in labor force attachment continuously falls from 37.1 in 1980 to 20.1 in 1997-1999, increases to 23.6 in 2000, and then falls thereafter (23.5 in 2001-2003, 22.6 in 2004-2006, and 21.1 in 2007-2009).

${ }^{26}$ If one pools the CPS over 1999-2001 in an attempt to get an approximation of the 2000 Census number (41.6), the child penalty is 42.0 , which is very much in line with the Census data.

${ }^{27}$ This is generally true for all levels of education, although it is noisier in the 1990's for white married women with less than high school due to small cell sizes. Moreover, this holds true for white married college educated women across the age distribution.
} 
Table 4 presents the decomposition of the overall child penalty for white college educated married women by year and 4 age groups, 25-29, 30-34, 35-39, and $40-44 .^{28}$ Not surprisingly the overall child penalty is smaller for the youngest women (25-29) and steadily increases until the oldest age group (40-44) where it begins to decline irrespective of year. For example, in 2000 the overall child penalty is 34.12, 42.77, 45.47, and 41.89 for white college educated married women aged 25-29, 30-44, 35-39, and 40-44, respectively. Moreover, the intensive margin is of greater importance for young women relative to their older counterparts for all years. This lends support to the hypothesis that work behavior differs by age. Despite these age differences, there continues to be little support for the opt-out revolution for white college educated married women. In particular, the overall child penalty falls substantially between 1980 and 1990, and continues to fall between 1990 and 2000 although to a lesser extent, irrespective of the age group considered. ${ }^{29}$

Table 5 presents the decomposition of the overall child penalty by year and occupation. I focus on managerial/professional occupations for a number of reasons. First, managerial/professional occupations tend to be the focus of the media (see Williams et al., 2006). Second, lack of work place flexibility in these occupations (see Stone 2008) may result in women choosing to exit the labor market entirely on the one hand while on the other hand extreme hours in these types of occupations may afford women the ability to reduce their hours in light of new family responsibilities. This further highlights the importance of accounting for both the extensive and intensive when examining managerial/professional occupations.

\footnotetext{
${ }^{28}$ Appendix Table 3 reveals that the results are very similar if I instead employ a cohort analysis, that is, I do not find evidence of the opt-out phenomenon among white college educated married women. Specifically, support of the opt-out phenomenon requires that the overall child penalty rises for more recent birth cohorts relative to earlier birth cohorts. I find, however, that the overall child penalty becomes smaller as one moves from earlier birth cohorts to more recent birth cohorts for all age groups for white married college educated married women.

${ }^{29}$ The patterns by age groups mirror those for the overall college educated sample for blacks, Hispanics, and Asians presented in Table 2. Results are available upon request.
} 
Table 5 reveals that white college educated married women in managerial/professional occupations are more likely to adjust their hours (conditional on working) than exit the labor market, suggesting ignoring the intensive margin (as Belkin 2003 suggests) misses a large portion of the story. Despite this, it is still the case that white college educated married women in managerial/professional occupations experience a fall in the overall child penalty between 1990 and 2000 (36.29 to 32.05).

Looking at all managerial/professional occupations, however, combines all occupations irrespective of their gender mix. Given work-place flexibility and extreme hours likely vary a great deal by an occupation's gender mix, I look at detailed occupations in three occupation categories: male dominated occupations (architects, electrical engineers, physicians, lawyers, clergy/religious workers), female dominated occupations (registered nurses, dieticians/nutritionists, occupational therapists, primary school teachers, and librarians), and mixed occupations (human resources, accountants and auditors, secondary school teachers, economists, and editors/reporters). See the data section for a detailed discussion of occupation definitions.

The results are striking. For male dominated occupations the child penalty in unconditional annual hours generally falls between 1980 and 1990 and generally increases between 1990 and 2000. ${ }^{30}$ For example, the child penalty in unconditional annual hours

\footnotetext{
30 The main exception is clergy/religious workers. This occupation category, as defined by the Census (http://www.census.gov/hhes/www/ioindex/ioindex02/txtnew02.html\#21-2099) includes clergy ("Conduct religious worship and perform other spiritual functions associated with beliefs and practices of religious faith or denomination. Provide spiritual and moral guidance and assistance to members."), directors, religious activities and education ("Direct and coordinate activities of a denominational group to meet religious needs of students. Plan, direct, or coordinate church school programs designed to promote religious education among church membership. May provide counseling and guidance relative to marital, health, financial, and religious problems."), and all other religious workers ("All religious workers not listed separately.”). The latter two categories are likely dominated by women, make up the bulk of the women in the overall clergy/religious workers occupation, and more closely resemble occupations in female dominated occupations (e.g., teachers). The overall results for clergy/religious workers, therefore, more closely align with female dominated, rather than male dominated occupations.
} 
increased from 35.2 to 39.5 for architects between 1990 and 2000. This rise between 1990 and 2000 is in sharp contrast to the patterns found for female dominated occupations (with the exception of dieticians/nutritionists) and mixed occupations. ${ }^{31}$ Perhaps not surprisingly, women are generally more likely to adjust their hours of work (conditional on working) in male dominated occupations. In female dominated occupations, the importance of the intensive margin varies depending on specialty. In the medical specialty (i.e., registered nurses, dieticians/nutritionists, occupational therapists) the intensive margin is of more importance than in the education specialty (i.e., primary school teachers, and librarians). For mixed occupations, the relative role of the extensive and intensive margin is closer together, particularly in earlier years. These patterns illustrate that accounting for differences in work-place flexibility and the incidence of extreme hours across occupations is important. Moreover, these patterns provide support for the popular press' notion of the opt-out revolution, particularly among white college educated married women in male dominated occupations.

\section{Conclusion}

The "opt-out revolution" was first sensationalized in a 2003 New York Times article by Lisa Belkin and suggests that highly educated women (relative to their less educated counterparts) are exiting the labor market to care for their children more in recent years, that is, highly educated women face a higher child penalty than their less educated counterparts. This spurred a flurry of media attention to the issue, as well as increased interest among academics across the social sciences. The majority of the studies examine the employment side of the opt-

31 Analysis on alternative female dominated occupations and mixed occupations yield similar results and are available upon request. 
out revolution (i.e., conditional on having children women exit the labor market). ${ }^{32}$ With the exception of Vere (2007), they find little support for the media's account of highly educated women's recent exodus from the labor market to care for their children (see for example, Boushey 2005, Goldin 2006, Cohany and Sok 2007, Fortin 2008, and Percheski 2008).

The purpose of this study is to further document the evidence on the employment side of the opt-out revolution by allowing for differential effects of children on female labor supply by race, marital status, and occupation, as well as examining both the extensive margin (i.e., the decision to work a positive number of hours) and the intensive margin (i.e., conditional on participating in the labor market, the decision to adjust annual hours of work) of female labor supply.

Using the 1980, 1990, and 2000 U.S. Census, I find little evidence to support the opt-out revolution if one focuses solely on the extensive margin. In other words, I do not find that the child penalty for college educated women increased in recent years (1990 to 2000) irrespective of marital status or race. What is true, however, is that the child penalty falls substantially between 1980 and 1990 for all education levels and the penalty continues to fall (although to a lesser extent) for less educated women between 1990 and 2000 while the penalty remains flat during this time period for their college educated counterparts.

The patterns are very different if one focuses on the overall child penalty (based on both the extensive and intensive margins of labor supply). While the overall child penalty falls between 1990 and 2000 for white and Hispanic college educated married women, the opposite

\footnotetext{
${ }^{32}$ There are several other aspects of the opt-out literature. Vere (2007), Percheski (2008), and Shang and Weinberg (2009) examine the fertility side of opting out. Goldin and Katz (2008), Herr and Wolfram (2009), and Bertrand, Goldin, and Katz, (2009) examine the impact of opting out on labor market outcomes among alumni at Harvard University and the University of Chicago's Booth School of Business, respectively. Stone and Lovejoy (2004), Hewlett et al. (2005), Williams et al. (2006), Hewlett (2007), and Stone (2008) seek to understand why highly educated women are exiting the labor market and what the associated costs of exiting may be.
} 
pattern is found for their black and Asian counterparts. In addition, I find that the overall child penalty increases between 1990 and 2000 for white college educated married women who are in male dominated occupations, while the same is not true for female dominated occupations or mixed occupations. Overall, these patterns provide some evidence in support of the opt-out revolution, particularly for the group of women that tend to be the focus of the media, that is, white married college educated women in male dominated occupations.

Future work is needed to provide explanations for the patterns documented in this paper. Why do the opt-out patterns vary by race? Is it an artifact of cultural factors (i.e., different preferences for work and family)? Why do women opt-out? Is it family pulls (e.g., birth of a child), or is it work-place pushes (e.g., lack of flexibility on the job)? Or is it a combination of the two $?^{33}$ Does the importance of pulls vs. pushes vary by race? Conditional on exiting the labor market, how long do women remain out of the labor market? What types of occupations do they transition back into? How long do the transitions back into the labor market typically take? ${ }^{34}$ Does race play a role in re-entry? Why do the opt-out patterns vary by occupation? Is it an artifact of differences in work- place flexibility and the incidence of extreme hours?

\footnotetext{
33 There is a growing literature that is investigating this, although it is generally focused on highly educated professional women (see Stone and Lovejoy 2004, Hewlett et al. 2005, Hewlett 2007, Stone 2008, and Herr and Wolfram 2009).

${ }^{34}$ Hewlett et al. (2005) and Hewlett (2007) provide evidence on re-entry for highly qualified professionals.
} 


\section{References}

Antecol, Heather and Michael Steinberger, 2009. "Labor Supply Differences between Married Heterosexual Women and Partnered Lesbians: A Semi-Parametric Decomposition Approach.” Working Paper.

Belkin, Lisa. 2003. “The Opt-Out Revolution.” New York Times Magazine, Oct. 26, 42-47, 58, 85-86.

Bertrand, Marianne, Claudia Goldin, and Lawrence F. Katz, 2009. "Dynamics of the Gender Gap for Young Professionals in the Financial and Corporate Sectors.” Working Paper.

Boushey, Heather. 2005. “Are Women Opting Out? Debunking the Myth.” Center for Economic Policy Research, Briefing Paper (Nov).

Cha, Youngjoo, 2009. "Reinforcing the 'Separate Spheres' Arrangement: The Effect of Spousal Overwork on the Employment of Men and Women in Dual-Earner Households." American Sociological Review, Forthcoming.

Cohany, Sharon R. and Emy Sok, 2007. "Trends in Labor Force Participation of Married Mothers of Infants.” Monthly Labor Review (Feb), 9-16.

Fortin, Nicole, 2008. “Gender Role Attitudes and Women’s Labor Market Participation: OptingOut and the Persistent Appeal of Housewifery.” Working Paper.

Goldin, Claudia, 2006. "The Quiet Revolution that Transformed Women's Employment, Education, and Family." American Economic Review Papers and Proceedings, Vol 96 (2), 1-21.

Goldin, Claudia and Lawrence Katz, 2008. "Transitions: Career and Family Life Cycles of the Educational Elite.” American Economic Review Papers and Proceedings, Vol. 98 (2), 363-369.

Herr, Jane Leber and Catherine Wolfram, 2009. "Opt-Out Rates at Motherhood across HighEducation Career Paths: Selection Versus Work Environment.” NBER Working Paper \# 14717.

Hewlett, Syliva Ann, Carolyn Buck Luce, Peggy Shiller, and Sandra Southwell, 2005. “The Hidden Brain Drain: Off-Ramps and On-Ramps in Women’s Careers.” Harvard Business Review Research Report 9491 (March).

Hewlett, Sylvia Ann. 2007. Off-Ramps and On-Ramps: Keeping Talented Women on the Road to Success. Boston, MA: Harvard Business School Press. 
Percheski, Christine, 2008. “Opting Out? Cohort Differences in Professional Women's Employment Rates from 1960 to 2005.” American Sociological Review 73(June), 497517.

Ruggles, Steven, Matthew Sobek, Trent Alexander, Catherine A. Fitch, Ronald Goeken, Patricia Kelly Hall, Miriam King, and Chad Ronnander. 2004. Integrated Public Use Microdata Series: Version 3.0 (machine-readable database). Minneapolis, Minn.: Minnesota Population Center (producer and distributor). Available at http://usa.ipums.org/usa/.

Shang, Qingyan and Bruce Weinberg, 2009. “Opting for Families: Recent Trends in the Fertility of Highly Educated Women.” Working Paper.

Stone, Pamela and Meg Lovejoy, 2004. "Fast-Track Women and the "Choice” to Stay Home.” The Annals of the American Academy, V. 596 (November), 62-83.

Stone, Pamela. 2008. Opting Out? Why Women Really Quit Careers and Head Home. Berkeley, CA: University of California Press.

Story, Louise, 2005. “Many Women at Elite Colleges Set Career Path to Motherhood.” New York Times, Sept 20, p. A1.

Trunk, P., 2005. “New Generation Puts the Focus on Family.” The Boston Globe, Apr. 17, G1.

Vere, James P. 2007. “'Having it All’ No Longer: Fertility, Female Labor Supply, and the New Life Choices of Generation X.” Demography 44(4), 821-828.

Wallis, Claudia, 2004. “The Case for Staying Home.” Time Magazine, March 22, p. 50.

Williams, Joan, Jessica Manvell and Stephanie Bornstein, 2006. “‘Opt-Out’ or Pushed Out?: How the Press Covers Work/Family Conflict. The Untold Story of Why Women Leave the Workforce.” Working Paper, Work Life Law, UC Hastings College of Law. 
Figure 1. Labor Force Attachment (LFA) by Presence of Young Children, Education, and Year

(Women Aged 25-44)

Child penalty calculated as: [(LFA No Kids-LFA Kids Less Than 5)/(LFA No Kids)]*100

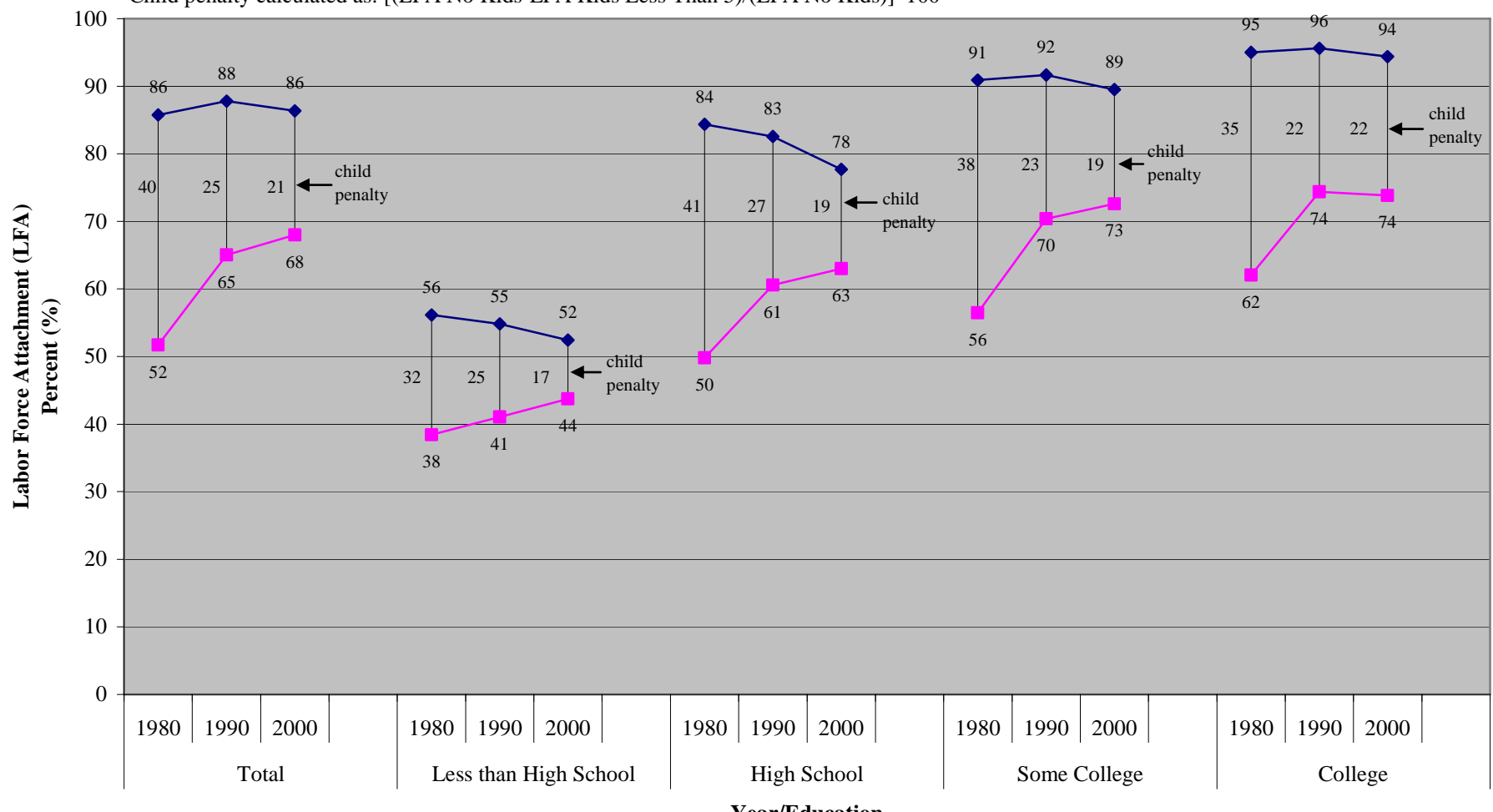

Year/Education

No Kids - Kids Less Than 5

Figure 2. Labor Force Attachment (LFA) by Presence of Children, Education, Year (Married Women Aged 25-44)

Child penalty calculated as: [(LFA No Kids-LFA Kids Less Than 5)/(LFA No Kids)]*100

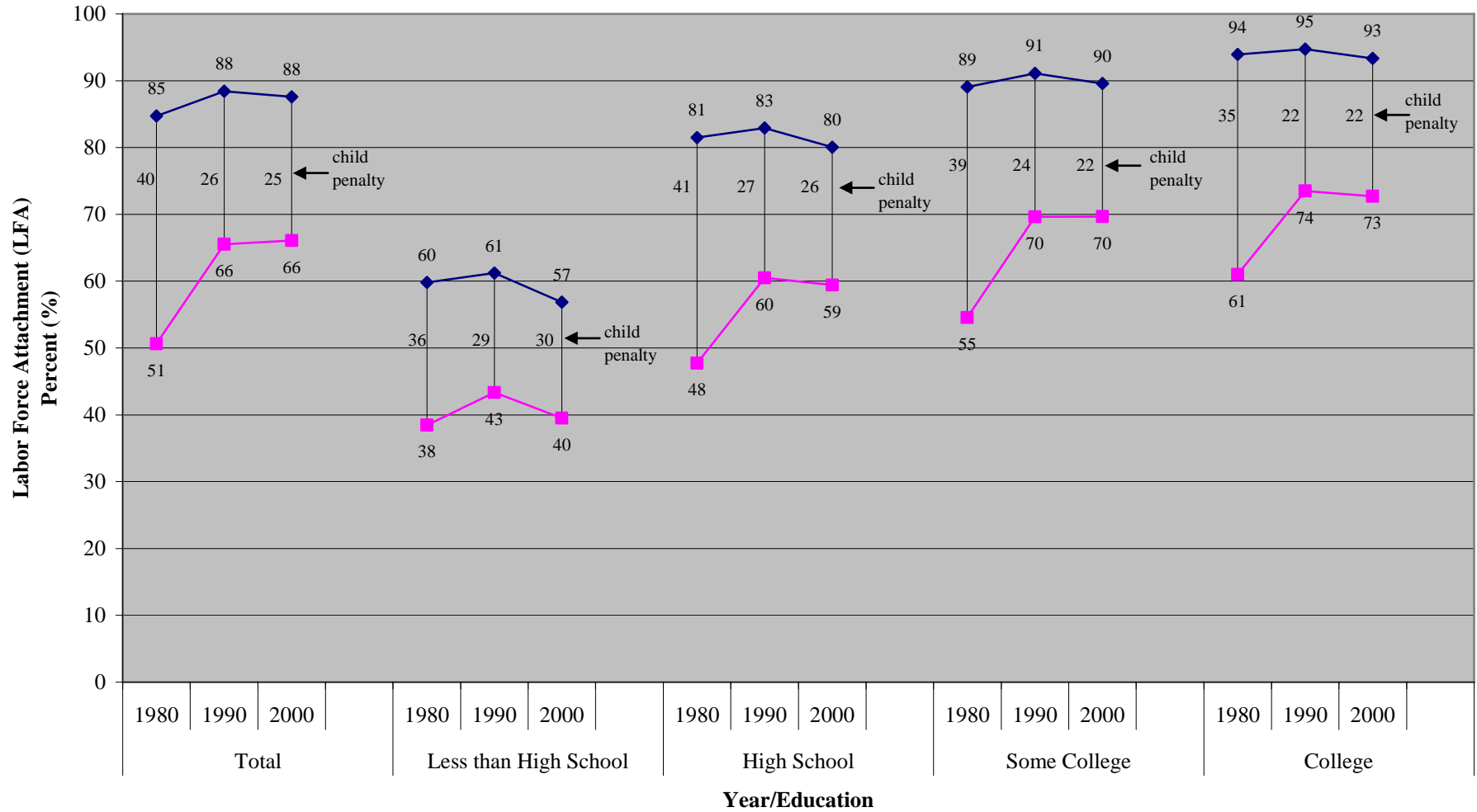


Figure 3. Labor Force Attachment (LFA) by Presence of Young Children, Education, Year (Married Non-Hispanic White Women Aged 25-44)

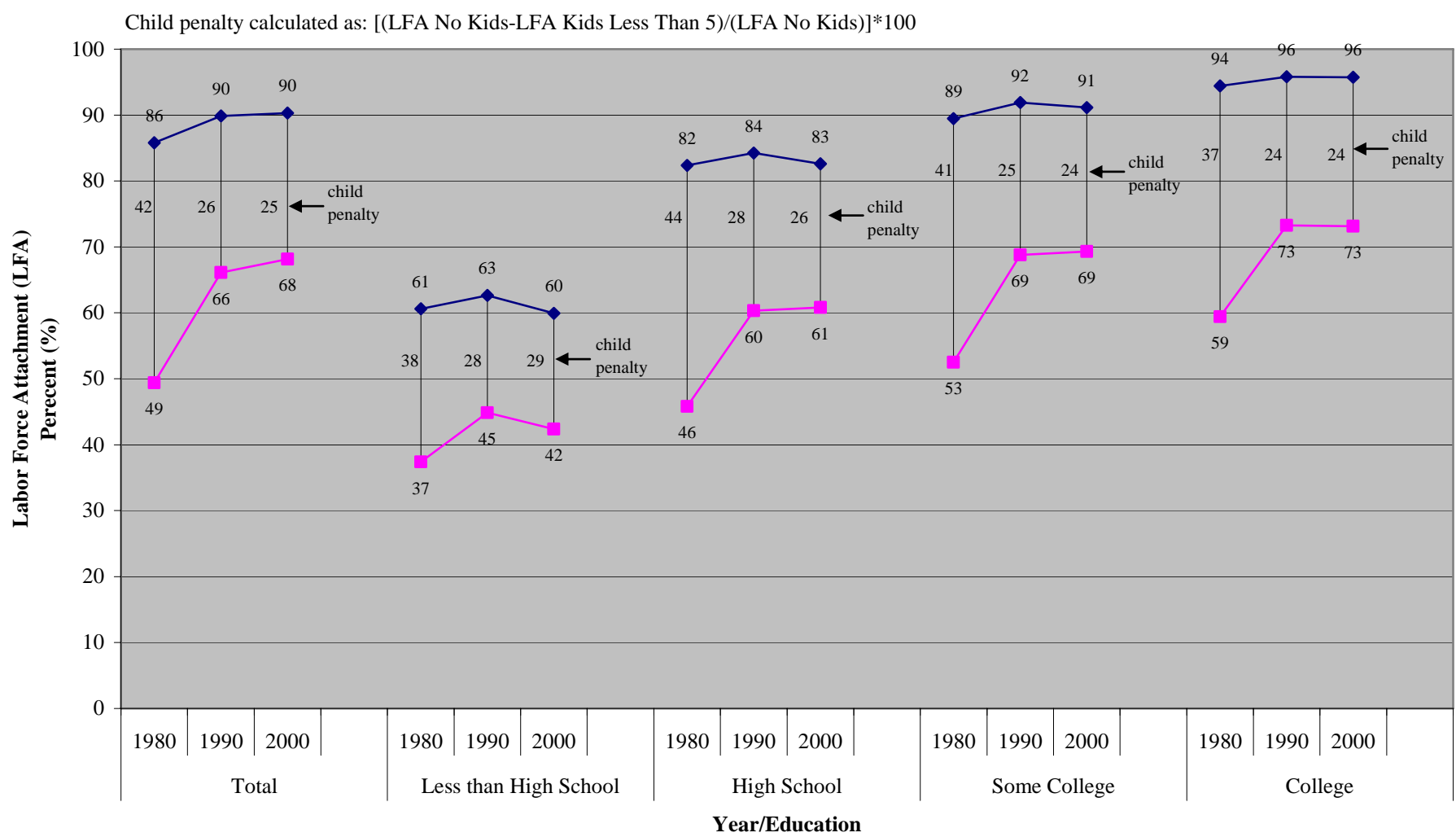

No Kids - - Kids Less Than 5

Figure 4. Labor Force Attachment (LFA) by Presence of Young Children, Education, Year (Married Non-Hispanic Black Women Aged 25-44)

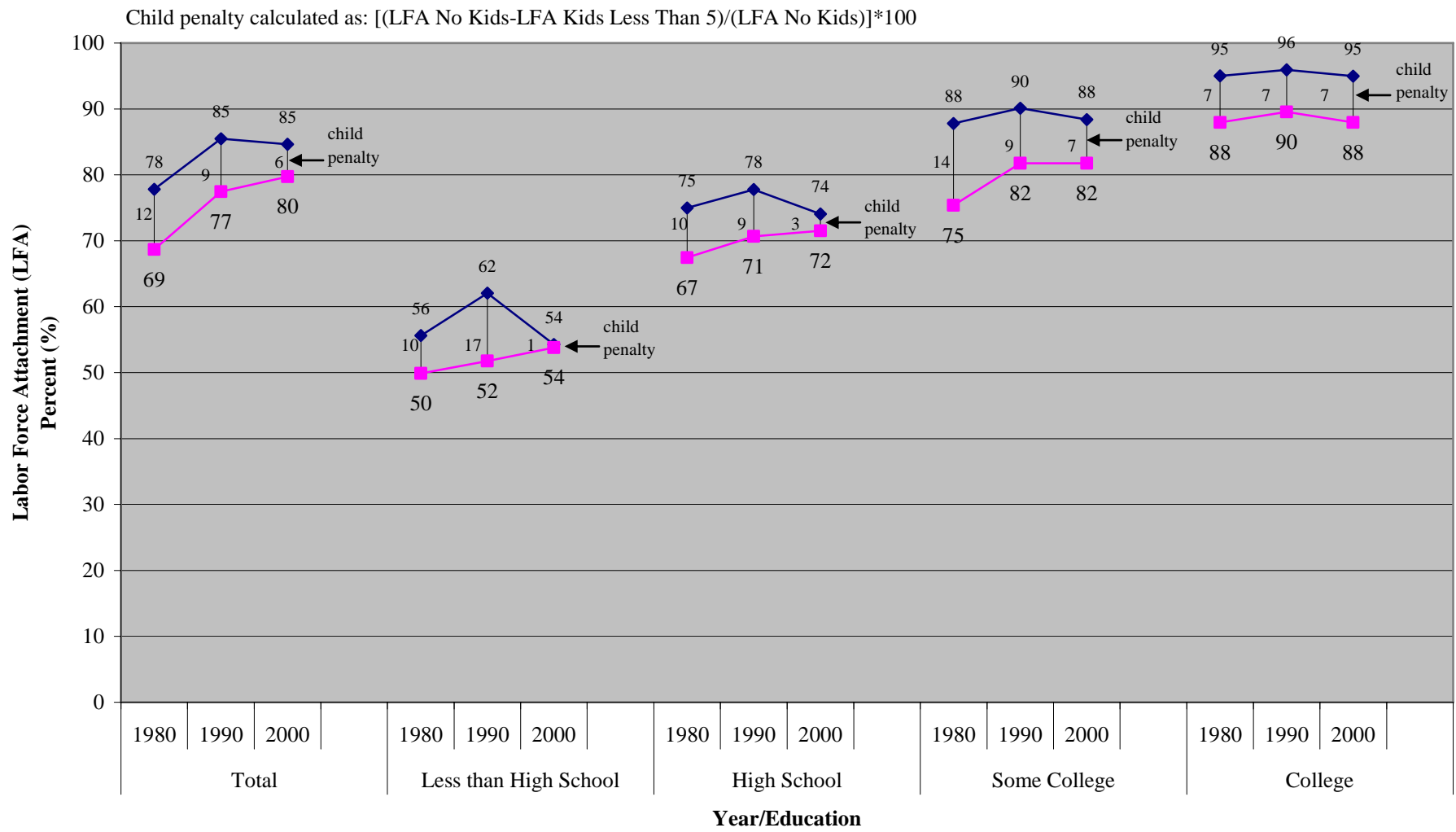


Figure 5. Labor Force Attachment (LFA) by Presence of Children, Education, Year (Married Hispanic Women Aged 25-44)

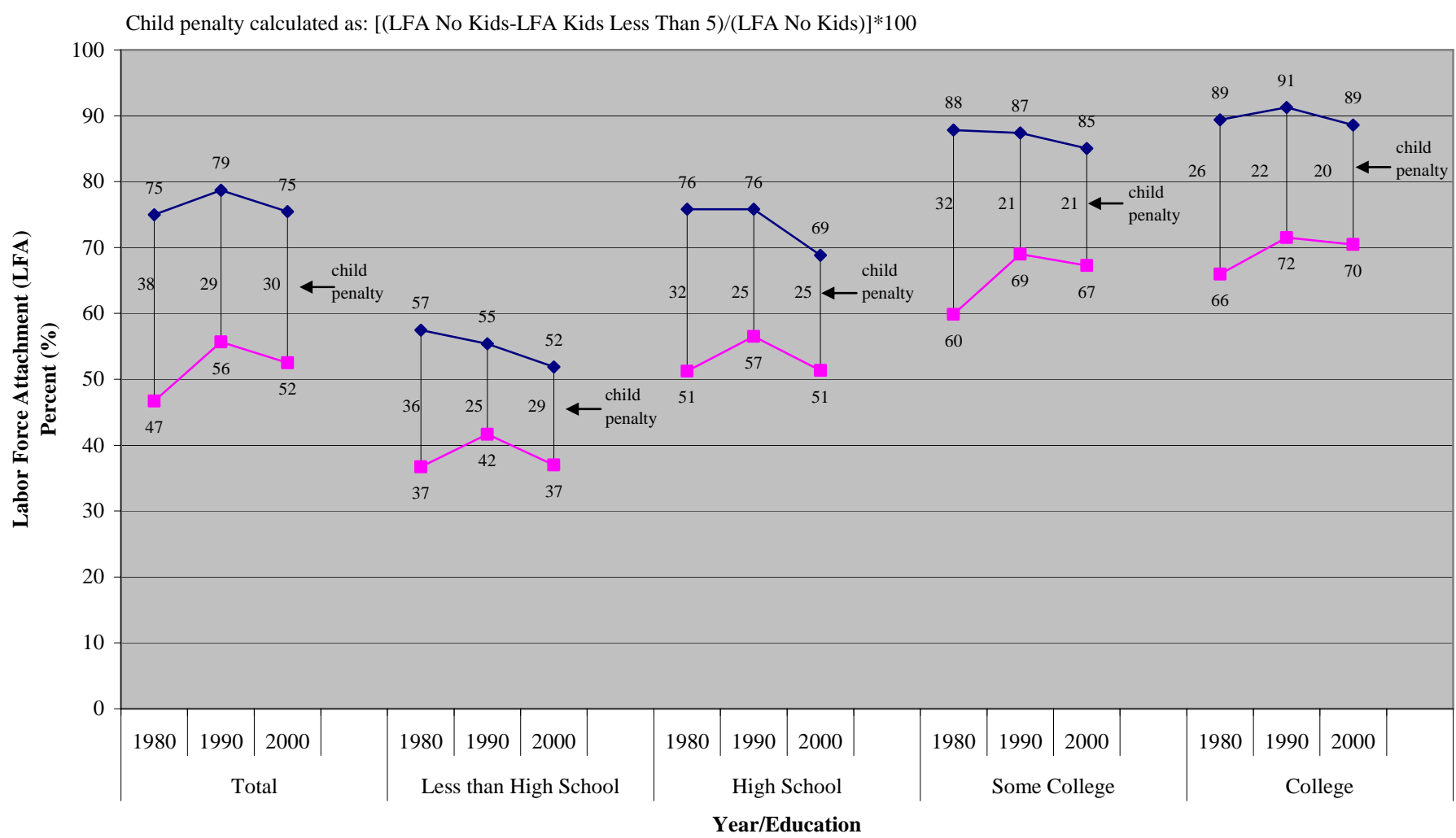

No Kids - - Kids Less Than 5

Figure 6. Labor Force Attachment (LFA) by Presence of Young Children, Education, Year (Married Asian Women Aged 25-44)

Child penalty calculated as: [(LFA No Kids-LFA Kids Less Than 5)/(LFA No Kids)]*100

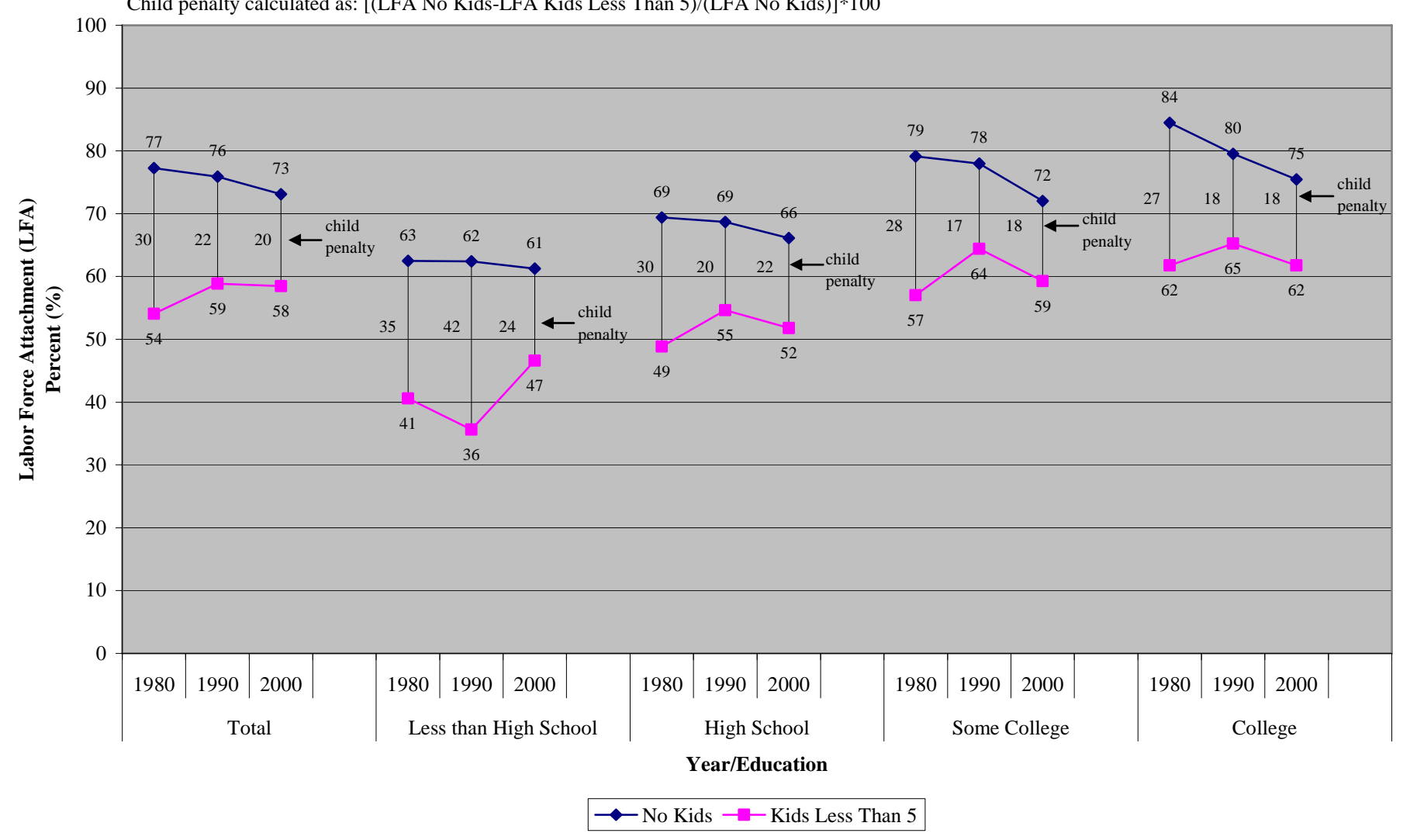


Figure 7. Unconditional Annual Hours (AHRS) by Presence of Children, Education, Year

(Married Women Aged 25-44)

Child penalty calculated as: [(AHRS No Kids-AHRS Kids Less Than 5)/(AHRS No Kids)]*100

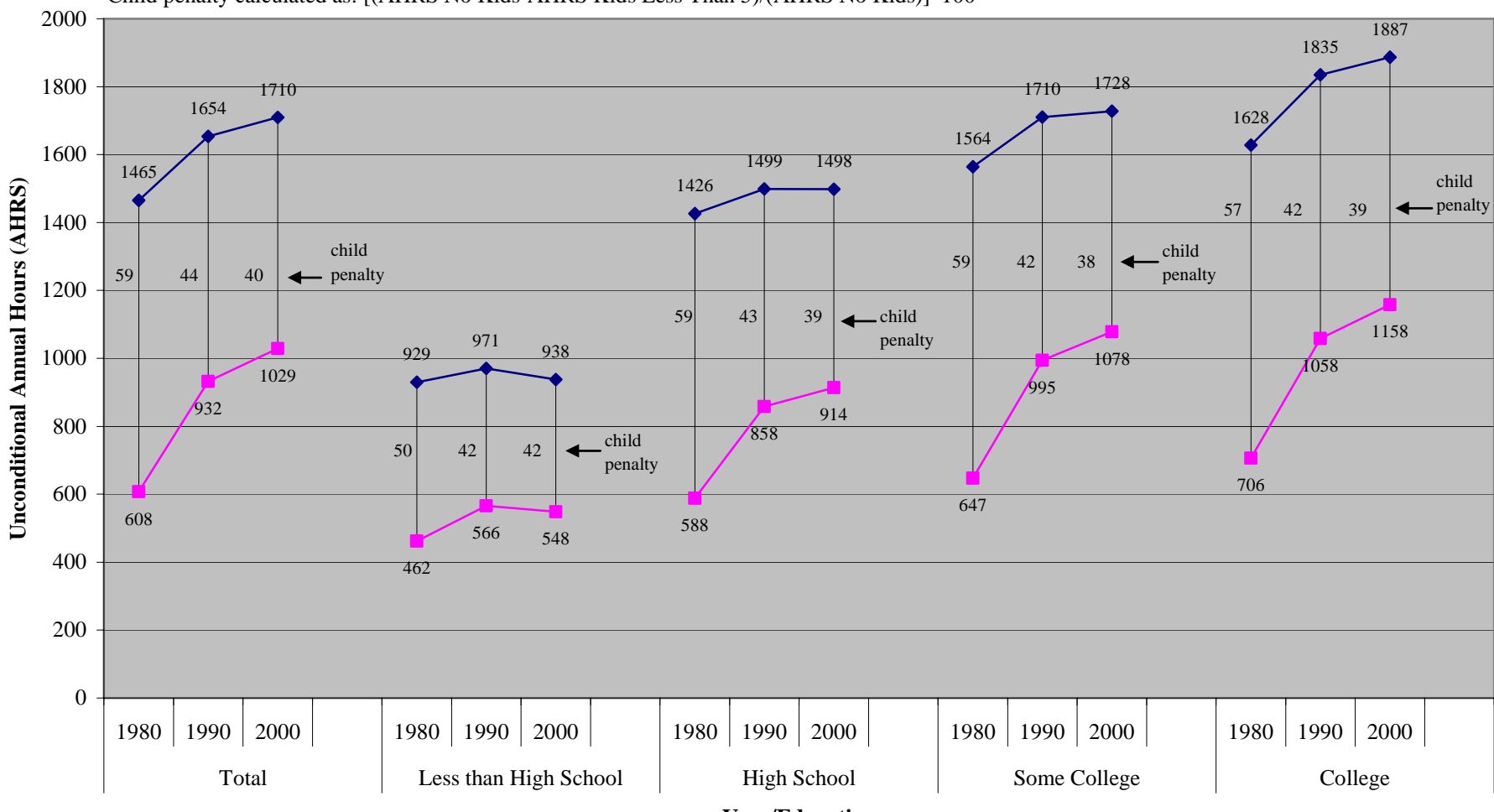

Year/Education

No Kids - Kids Less Than 5

Figure 8. Unconditional Annual Hours (AHRS) by Presence of Young Children, Education, Year (Married Non-Hispanic White Women Aged 25-44)

Child penalty calculated as: [(AHRS No Kids-AHRS Kids Less Than 5)/(AHRS No Kids)]*100

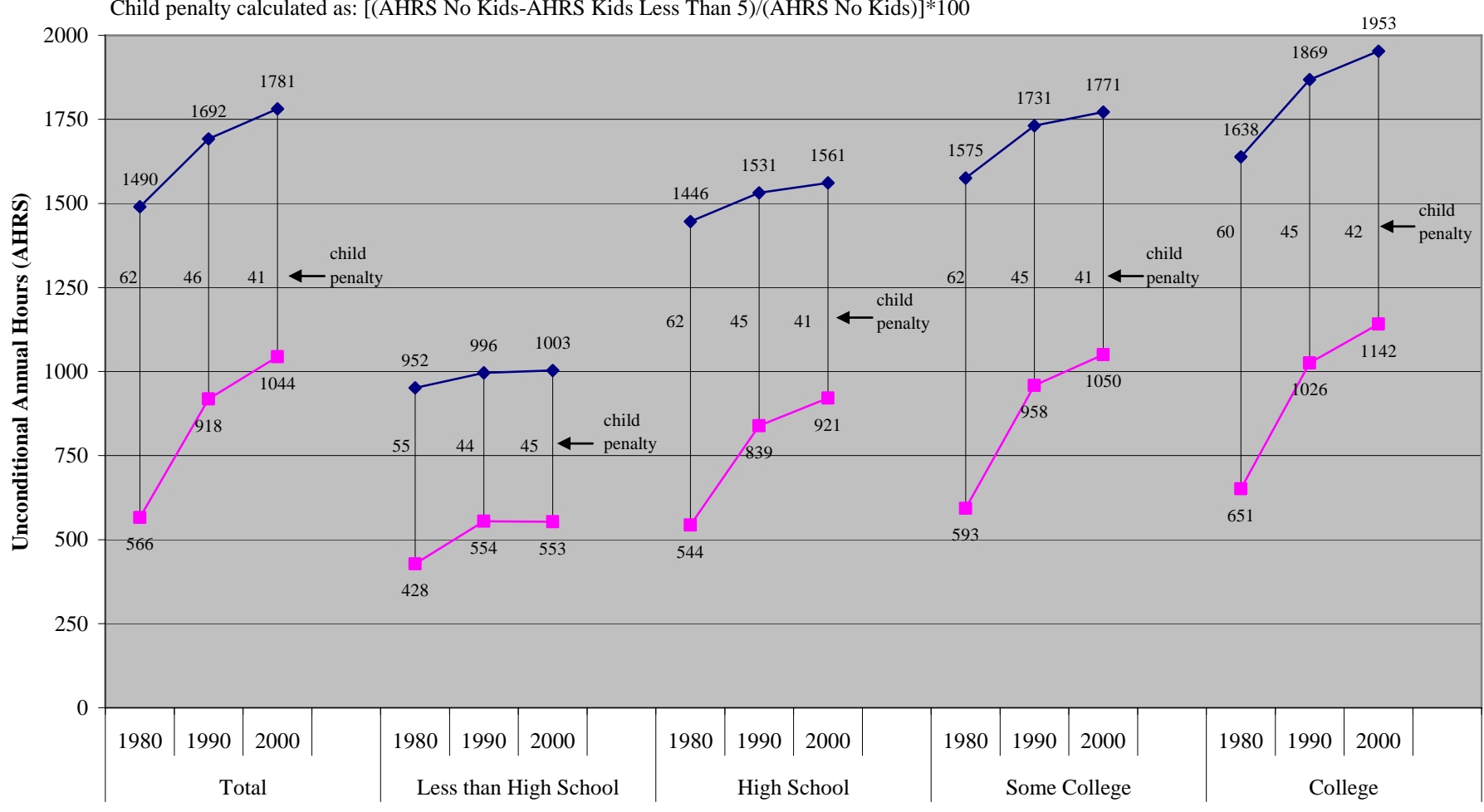

Year/Education 
Figure 9. Unconditional Annual Hours (AHRS) by Presence of Young Children, Education, Year

(Married Non-Hispanic Black Women Aged 25-44)

Child penalty calculated as: [(AHRS No Kids-AHRS Kids Less Than 5)/(AHRS No Kids)]*100

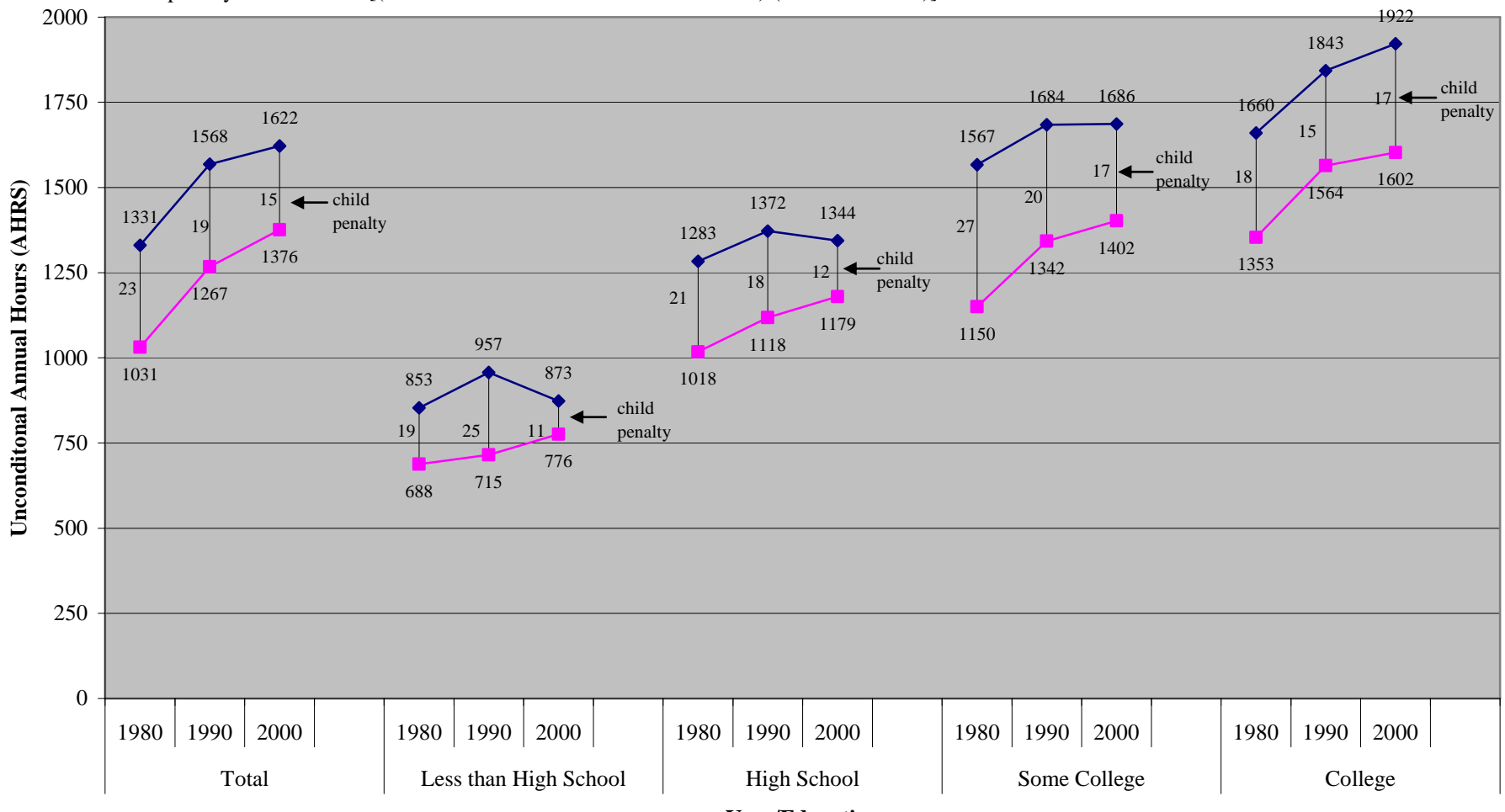

Year/Education

No Kids $\rightarrow$ Kids Less Than 5

Figure 10. Unconditional Annual Hours (AHRS) by Presence of Children, Education, Year (Married Hispanic Women Aged 25-44)

Child penalty calculated as: [(AHRS No Kids-AHRS Kids Less Than 5)/(AHRS No Kids)]*100

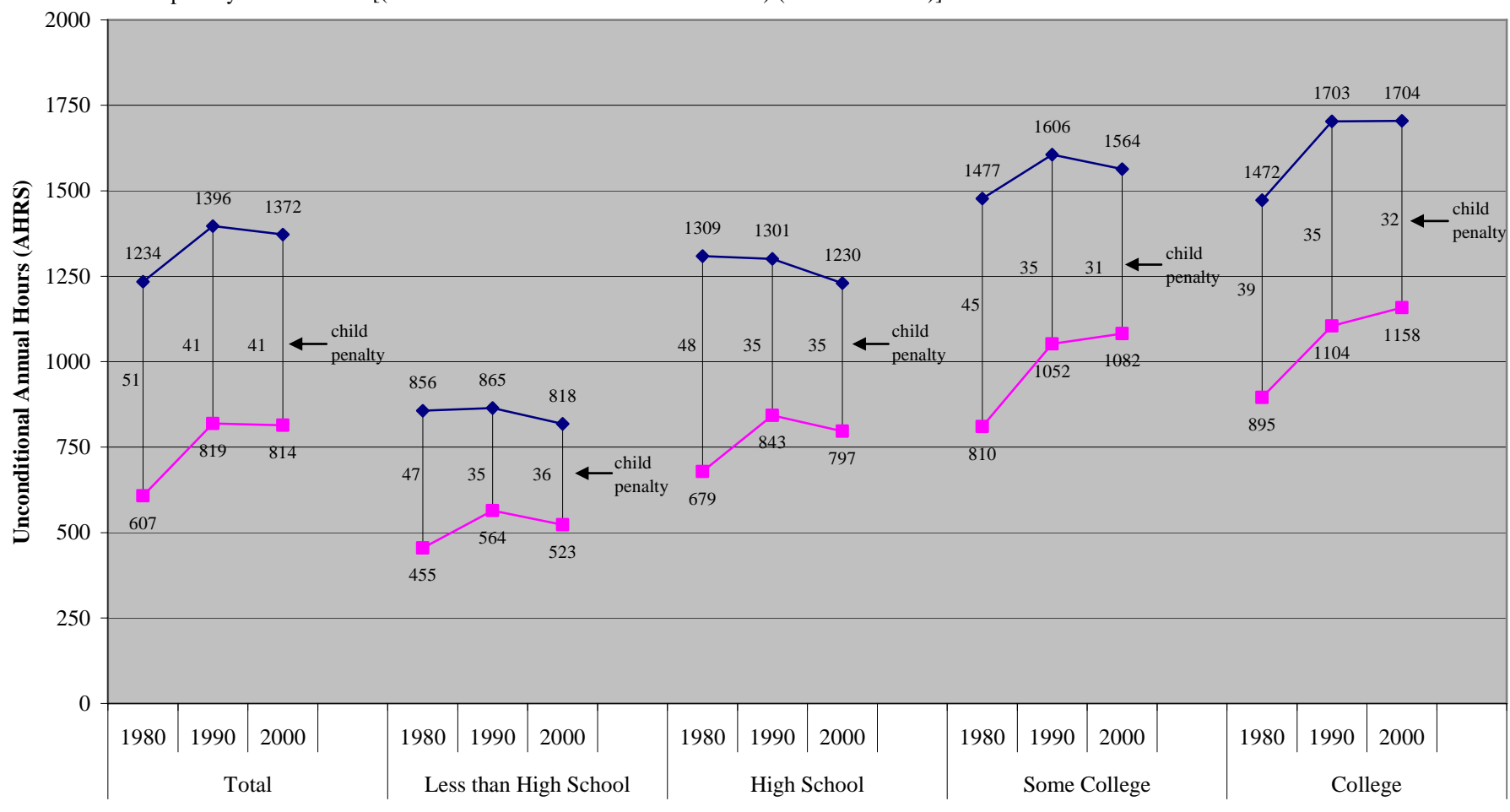

Year/Education 
Figure 11. Unconditional Annual Hours (AHRS) by Presence of Young Children, Education, Year (Married Asian Women Aged 25-44)

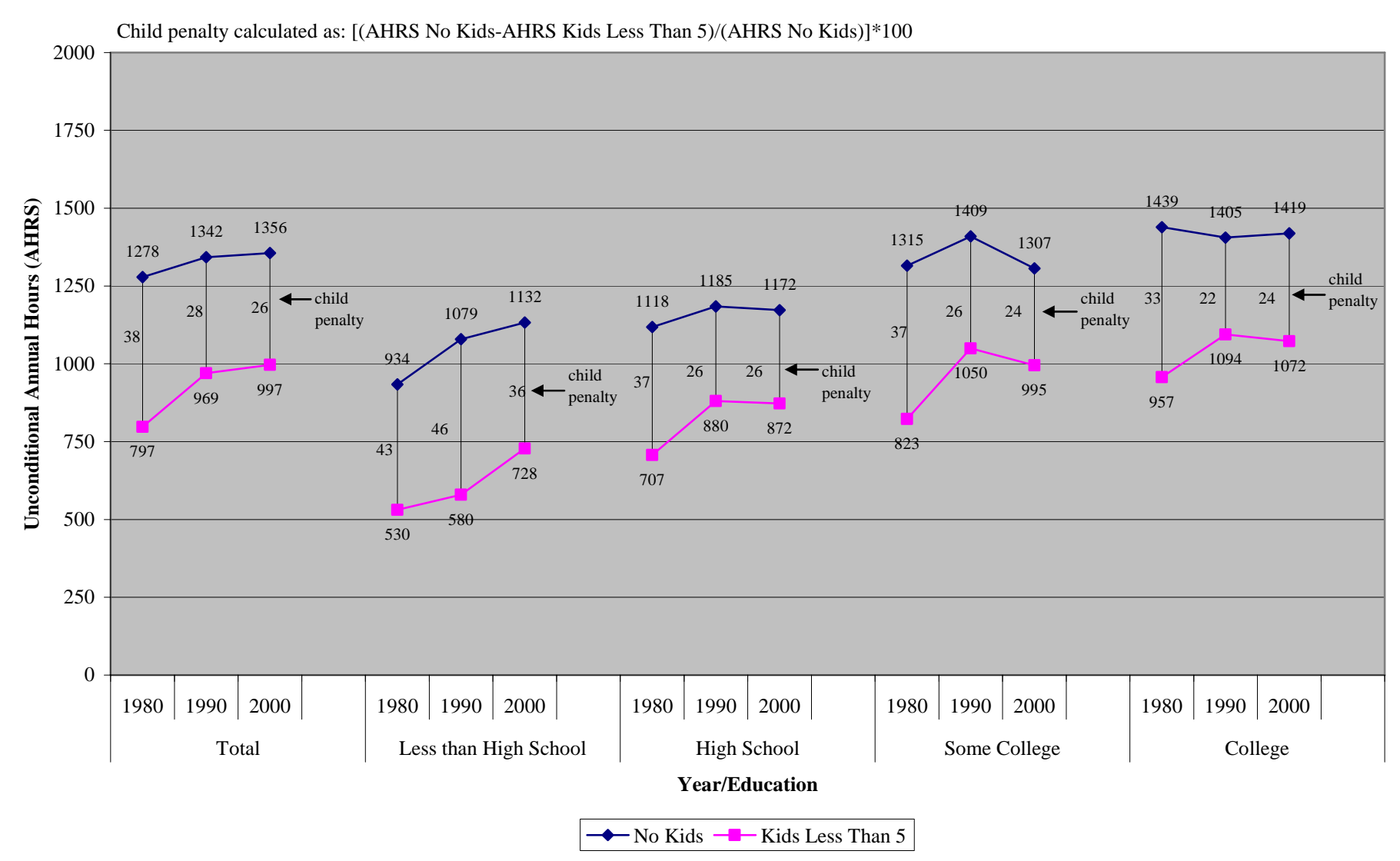


Table 1. Summary Statistics by Race/Ethnicity and Year

(Women Aged 25-44)

\begin{tabular}{|c|c|c|c|c|c|c|c|c|c|c|c|c|c|c|c|}
\hline & \multicolumn{3}{|c|}{ Total } & \multicolumn{3}{|c|}{ Non-Hispanic White } & \multicolumn{3}{|c|}{ Non-Hispanic Black } & \multicolumn{3}{|c|}{ Hispanic } & \multicolumn{3}{|c|}{ Asian } \\
\hline & $\begin{array}{c}1980 \\
(1)\end{array}$ & $\begin{array}{c}1990 \\
(2)\end{array}$ & $\begin{array}{c}2000 \\
(3)\end{array}$ & $\begin{array}{c}1980 \\
(4)\end{array}$ & $\begin{array}{c}1990 \\
(5)\end{array}$ & $\begin{array}{c}2000 \\
(6)\end{array}$ & $\begin{array}{c}1980 \\
(7)\end{array}$ & $\begin{array}{c}1990 \\
(8)\end{array}$ & $\begin{array}{c}2000 \\
(9)\end{array}$ & $\begin{array}{c}1980 \\
(10)\end{array}$ & $\begin{array}{c}1990 \\
(11)\end{array}$ & $\begin{array}{c}2000 \\
(12)\end{array}$ & $\begin{array}{c}1980 \\
(13)\end{array}$ & $\begin{array}{c}1990 \\
(14)\end{array}$ & $\begin{array}{c}2000 \\
(15)\end{array}$ \\
\hline \multicolumn{16}{|c|}{ Race/Ethnicity^^${ }^{\wedge}$} \\
\hline WHITE & 0.81 & 0.77 & 0.71 & & & & & & & & & & & & \\
\hline BLACK & 0.10 & 0.11 & 0.11 & & & & & & & & & & & & \\
\hline HISPANIC & 0.06 & 0.08 & 0.11 & & & & & & & & & & & & \\
\hline ASIAN & 0.02 & 0.03 & 0.05 & & & & & & & & & & & & \\
\hline \multicolumn{16}{|c|}{ Labor Supply } \\
\hline AHRS & 1032.74 & 1296.97 & 1393.57 & 1031.52 & 1327.86 & 1438.58 & 1131.59 & 1286.48 & 1444.46 & 866.78 & 1062.63 & 1125.51 & 1097.25 & 1244.07 & 1271.62 \\
\hline WKSWRK & 28.10 & 33.91 & 35.76 & 28.24 & 34.93 & 37.11 & 29.96 & 32.82 & 36.30 & 23.16 & 27.49 & 28.92 & 28.47 & 31.23 & 31.63 \\
\hline UHRS & 24.21 & 28.79 & 30.04 & 24.17 & 29.29 & 30.70 & 26.03 & 28.81 & 31.54 & 21.21 & 24.78 & 25.48 & 25.54 & 27.56 & 27.77 \\
\hline CAHRS* & 1519.44 & 1679.63 & 1770.24 & 1507.02 & 1676.94 & 1775.69 & 1609.80 & 1718.35 & 1795.67 & 1495.89 & 1626.96 & 1689.56 & 1620.49 & 1760.41 & 1804.16 \\
\hline LFA & 0.68 & 0.77 & 0.79 & 0.68 & 0.79 & 0.81 & 0.70 & 0.75 & 0.80 & 0.58 & 0.65 & 0.67 & 0.68 & 0.71 & 0.70 \\
\hline \multicolumn{16}{|l|}{ Education } \\
\hline LTHIGH & 0.18 & 0.11 & 0.09 & 0.15 & 0.07 & 0.05 & 0.29 & 0.15 & 0.10 & 0.46 & 0.35 & 0.32 & 0.18 & 0.13 & 0.08 \\
\hline HIGH & 0.44 & 0.33 & 0.28 & 0.46 & 0.34 & 0.27 & 0.41 & 0.37 & 0.33 & 0.33 & 0.30 & 0.29 & 0.26 & 0.22 & 0.17 \\
\hline SOMECOL & 0.19 & 0.32 & 0.34 & 0.20 & 0.33 & 0.35 & 0.19 & 0.33 & 0.38 & 0.13 & 0.24 & 0.25 & 0.19 & 0.25 & 0.23 \\
\hline COLLEGE & 0.19 & 0.24 & 0.30 & 0.20 & 0.26 & 0.33 & 0.11 & 0.15 & 0.19 & 0.07 & 0.10 & 0.14 & 0.38 & 0.40 & 0.52 \\
\hline \multicolumn{16}{|c|}{ Family Relationship } \\
\hline MARRIED & 0.73 & 0.66 & 0.63 & 0.77 & 0.70 & 0.68 & 0.47 & 0.37 & 0.35 & 0.69 & 0.62 & 0.63 & 0.78 & 0.73 & 0.71 \\
\hline NCHILD & 1.68 & 1.40 & 1.39 & 1.62 & 1.34 & 1.33 & 1.94 & 1.54 & 1.47 & 2.10 & 1.77 & 1.73 & 1.50 & 1.34 & 1.19 \\
\hline NCHLT5 & 0.35 & 0.35 & 0.34 & 0.34 & 0.34 & 0.33 & 0.34 & 0.32 & 0.29 & 0.48 & 0.44 & 0.42 & 0.44 & 0.38 & 0.36 \\
\hline NOKID & 0.25 & 0.32 & 0.33 & 0.26 & 0.33 & 0.34 & 0.23 & 0.28 & 0.31 & 0.20 & 0.26 & 0.27 & 0.30 & 0.35 & 0.39 \\
\hline KIDLT5 & 0.28 & 0.27 & 0.27 & 0.27 & 0.27 & 0.26 & 0.27 & 0.25 & 0.23 & 0.37 & 0.34 & 0.33 & 0.35 & 0.30 & 0.29 \\
\hline \multicolumn{16}{|l|}{ Age } \\
\hline AGE & 33.40 & 34.11 & 34.95 & 33.45 & 34.23 & 35.21 & 33.18 & 33.79 & 34.70 & 33.17 & 33.37 & 33.90 & 33.30 & 34.21 & 34.33 \\
\hline $\mathrm{N}$ & $1,296,068$ & $1,635,258$ & $1,589,181$ & $1,052,561$ & $1,283,288$ & $1,152,947$ & 131,166 & 158,876 & 164,045 & 76,955 & 126,889 & 165,967 & 26,514 & 51,220 & 65,403 \\
\hline
\end{tabular}

Source: U.S. Census (IPUMS). All observations with flagged values on any of the variables of interest are dropped from the analysis. Sampling weights used.

See Appendix Table 1 for variable definitions.

$\wedge$ Does not sum to one as Native Americans and other races not included.

*Number of observation is lower b/c they refer only to those working positive hours. 
Table 2. Decomposition of the Child Penalty in Unconditional Annual Hours by Race/Ethnicity, Year, and Education (Married Women Aged 25-44)

\begin{tabular}{|c|c|c|c|c|c|c|c|c|c|c|c|c|c|c|c|}
\hline & \multirow{2}{*}{\multicolumn{2}{|c|}{$\begin{array}{c}\text { Total } \\
1990 \\
(2)\end{array}$}} & \multirow[b]{2}{*}{$\begin{array}{c}2000 \\
(3)\end{array}$} & \multicolumn{3}{|c|}{ Non-Hispanic White } & \multicolumn{3}{|c|}{ Non-Hispanic Black } & \multicolumn{3}{|c|}{ Hispanic } & \multicolumn{3}{|c|}{ Asian } \\
\hline & & & & $\begin{array}{c}1980 \\
(4)\end{array}$ & $\begin{array}{c}1990 \\
(5)\end{array}$ & $\begin{array}{c}2000 \\
(6)\end{array}$ & $\begin{array}{l}1980 \\
(7)\end{array}$ & $\begin{array}{c}1990 \\
(8)\end{array}$ & $\begin{array}{c}2000 \\
(9)\end{array}$ & $\begin{array}{l}1980 \\
(10)\end{array}$ & $\begin{array}{l}1990 \\
(11)\end{array}$ & $\begin{array}{l}2000 \\
(12)\end{array}$ & $\begin{array}{l}1980 \\
(13)\end{array}$ & $\begin{array}{l}1990 \\
(14)\end{array}$ & $\begin{array}{l}2000 \\
(15)\end{array}$ \\
\hline \multicolumn{16}{|l|}{ Total } \\
\hline Child Penalty & 58.53 & 43.64 & 39.84 & 62.01 & 45.71 & 41.42 & 22.54 & 19.20 & 15.17 & 50.77 & 41.34 & 40.69 & 37.64 & 27.77 & 26.47 \\
\hline $\begin{array}{l}\text { Extensive Margin } \\
\% \text { Explained }\end{array}$ & $\begin{array}{c}40.20 \\
(68.68)\end{array}$ & $\begin{array}{c}25.89 \\
(59.32)\end{array}$ & $\begin{array}{c}24.55 \\
(61.62)\end{array}$ & $\begin{array}{c}42.41 \\
(68.40)\end{array}$ & $\begin{array}{c}26.40 \\
(57.74)\end{array}$ & $\begin{array}{c}24.53 \\
(59.22)\end{array}$ & $\begin{array}{c}11.71 \\
(51.93)\end{array}$ & $\begin{array}{c}9.40 \\
(48.94)\end{array}$ & $\begin{array}{c}5.80 \\
(38.21)\end{array}$ & $\begin{array}{c}37.73 \\
(74.31)\end{array}$ & $\begin{array}{c}29.26 \\
(70.79)\end{array}$ & $\begin{array}{c}30.41 \\
(74.74)\end{array}$ & $\begin{array}{c}30.01 \\
(79.73)\end{array}$ & $\begin{array}{c}22.46 \\
(80.87)\end{array}$ & $\begin{array}{c}20.02 \\
(75.65)\end{array}$ \\
\hline $\begin{array}{l}\text { Intensive Margin } \\
\% \text { Explained }\end{array}$ & $\begin{array}{c}18.34 \\
(31.32)\end{array}$ & $\begin{array}{c}17.76 \\
(40.68)\end{array}$ & $\begin{array}{c}15.29 \\
(38.38)\end{array}$ & $\begin{array}{c}19.60 \\
(31.60)\end{array}$ & $\begin{array}{c}19.32 \\
(42.26)\end{array}$ & $\begin{array}{c}16.89 \\
(40.78)\end{array}$ & $\begin{array}{c}10.84 \\
(48.07)\end{array}$ & $\begin{array}{c}9.80 \\
(51.06)\end{array}$ & $\begin{array}{c}9.37 \\
(61.79)\end{array}$ & $\begin{array}{c}13.04 \\
(25.69)\end{array}$ & $\begin{array}{c}12.07 \\
(29.21)\end{array}$ & $\begin{array}{c}10.28 \\
(25.26)\end{array}$ & $\begin{array}{c}7.63 \\
(20.27)\end{array}$ & $\begin{array}{c}5.31 \\
(19.13)\end{array}$ & $\begin{array}{c}6.44 \\
(24.35)\end{array}$ \\
\hline \multicolumn{16}{|c|}{ Less Than High School } \\
\hline Child Penalty & 50.29 & 41.69 & 41.54 & 55.01 & 44.36 & 44.89 & 19.39 & 25.26 & 11.14 & 46.90 & 34.73 & 36.06 & 43.19 & 46.30 & 35.72 \\
\hline $\begin{array}{l}\text { Extensive Margin } \\
\% \text { Explained }\end{array}$ & $\begin{array}{c}35.65 \\
(70.89)\end{array}$ & $\begin{array}{c}29.22 \\
(70.08)\end{array}$ & $\begin{array}{c}30.48 \\
(73.39)\end{array}$ & $\begin{array}{c}38.30 \\
(69.63)\end{array}$ & $\begin{array}{c}28.37 \\
(63.96)\end{array}$ & $\begin{array}{c}29.28 \\
(65.23)\end{array}$ & $\begin{array}{c}10.30 \\
(53.13)\end{array}$ & $\begin{array}{c}16.61 \\
(65.77)\end{array}$ & $\begin{array}{c}0.89 \\
(7.97)\end{array}$ & $\begin{array}{c}36.07 \\
(76.91)\end{array}$ & $\begin{array}{c}24.78 \\
(71.35)\end{array}$ & $\begin{array}{c}28.69 \\
(79.57)\end{array}$ & $\begin{array}{c}35.07 \\
(81.21)\end{array}$ & $\begin{array}{c}42.90 \\
(92.66)\end{array}$ & $\begin{array}{c}23.91 \\
(66.93)\end{array}$ \\
\hline $\begin{array}{l}\text { Intensive Margin } \\
\% \text { Explained }\end{array}$ & $\begin{array}{c}14.64 \\
(29.11)\end{array}$ & $\begin{array}{c}12.47 \\
(29.92)\end{array}$ & $\begin{array}{c}11.05 \\
(26.61)\end{array}$ & $\begin{array}{c}16.71 \\
(30.37)\end{array}$ & $\begin{array}{c}15.99 \\
(36.04)\end{array}$ & $\begin{array}{c}15.61 \\
(34.77)\end{array}$ & $\begin{array}{c}9.09 \\
(46.87)\end{array}$ & $\begin{array}{c}8.65 \\
(34.23)\end{array}$ & $\begin{array}{c}10.26 \\
(92.03)\end{array}$ & $\begin{array}{c}10.83 \\
(23.09)\end{array}$ & $\begin{array}{c}9.95 \\
(28.65)\end{array}$ & $\begin{array}{c}7.37 \\
(20.43)\end{array}$ & $\begin{array}{c}8.12 \\
(18.79)\end{array}$ & $\begin{array}{c}3.40 \\
(7.34)\end{array}$ & $\begin{array}{c}11.81 \\
(33.07)\end{array}$ \\
\hline \multicolumn{16}{|c|}{ High School } \\
\hline Child Penalty & 58.76 & 42.74 & 39.00 & 62.39 & 45.24 & 40.97 & 20.70 & 18.48 & 12.24 & 48.16 & 35.18 & 35.22 & 36.76 & 25.70 & 25.58 \\
\hline $\begin{array}{l}\text { Extensive Margin } \\
\% \text { Explained }\end{array}$ & $\begin{array}{c}41.43 \\
(70.51)\end{array}$ & $\begin{array}{c}27.05 \\
(63.29)\end{array}$ & $\begin{array}{c}25.79 \\
(66.13)\end{array}$ & $\begin{array}{c}44.38 \\
(71.13)\end{array}$ & $\begin{array}{c}28.38 \\
(62.74)\end{array}$ & $\begin{array}{c}26.41 \\
(64.46)\end{array}$ & $\begin{array}{c}10.10 \\
(48.80)\end{array}$ & $\begin{array}{c}9.15 \\
(49.50)\end{array}$ & $\begin{array}{c}3.45 \\
(28.15)\end{array}$ & $\begin{array}{c}32.42 \\
(67.33)\end{array}$ & $\begin{array}{c}25.49 \\
(72.45)\end{array}$ & $\begin{array}{c}25.38 \\
(72.06)\end{array}$ & $\begin{array}{c}29.58 \\
(80.47)\end{array}$ & $\begin{array}{c}20.43 \\
(79.52)\end{array}$ & $\begin{array}{c}21.63 \\
(84.58)\end{array}$ \\
\hline $\begin{array}{l}\text { Intensive Margin } \\
\% \text { Explained }\end{array}$ & $\begin{array}{c}17.33 \\
(29.49)\end{array}$ & $\begin{array}{c}15.69 \\
(36.71)\end{array}$ & $\begin{array}{c}13.21 \\
(33.87)\end{array}$ & $\begin{array}{c}18.01 \\
(28.87)\end{array}$ & $\begin{array}{c}16.86 \\
(37.26)\end{array}$ & $\begin{array}{c}14.56 \\
(35.54)\end{array}$ & $\begin{array}{c}10.60 \\
(51.20)\end{array}$ & $\begin{array}{c}9.33 \\
(50.50)\end{array}$ & $\begin{array}{c}8.80 \\
(71.85)\end{array}$ & $\begin{array}{c}15.73 \\
(32.67)\end{array}$ & $\begin{array}{c}9.69 \\
(27.55)\end{array}$ & $\begin{array}{c}9.84 \\
(27.94)\end{array}$ & $\begin{array}{c}7.18 \\
(19.53)\end{array}$ & $\begin{array}{c}5.26 \\
(20.48)\end{array}$ & $\begin{array}{c}3.94 \\
(15.42)\end{array}$ \\
\hline \multicolumn{16}{|c|}{ Some College } \\
\hline Child Penalty & 58.65 & 41.84 & 37.61 & 62.36 & 44.65 & 40.71 & 26.58 & 20.28 & 16.83 & 45.15 & 34.50 & 30.80 & 37.44 & 25.53 & 23.85 \\
\hline $\begin{array}{l}\text { Extensive Margin } \\
\% \text { Explained }\end{array}$ & $\begin{array}{c}38.75 \\
(66.08)\end{array}$ & $\begin{array}{c}23.58 \\
(56.36)\end{array}$ & $\begin{array}{c}22.22 \\
(59.09)\end{array}$ & $\begin{array}{c}41.29 \\
(66.21)\end{array}$ & $\begin{array}{c}25.13 \\
(56.29)\end{array}$ & $\begin{array}{c}23.97 \\
(58.88)\end{array}$ & $\begin{array}{c}14.14 \\
(53.18)\end{array}$ & $\begin{array}{c}9.28 \\
(45.77)\end{array}$ & $\begin{array}{c}7.48 \\
(44.41)\end{array}$ & $\begin{array}{c}31.84 \\
(70.52)\end{array}$ & $\begin{array}{c}21.06 \\
(61.04)\end{array}$ & $\begin{array}{c}20.88 \\
(67.78)\end{array}$ & $\begin{array}{c}27.93 \\
(74.61)\end{array}$ & $\begin{array}{c}17.42 \\
(68.24)\end{array}$ & $\begin{array}{c}17.73 \\
(74.35)\end{array}$ \\
\hline $\begin{array}{l}\text { Intensive Margin } \\
\text { \% Explained }\end{array}$ & $\begin{array}{c}19.90 \\
(33.92)\end{array}$ & $\begin{array}{c}18.26 \\
(43.64)\end{array}$ & $\begin{array}{c}15.39 \\
(40.91)\end{array}$ & $\begin{array}{c}21.07 \\
(33.79)\end{array}$ & $\begin{array}{c}19.52 \\
(43.71)\end{array}$ & $\begin{array}{c}16.74 \\
(41.12)\end{array}$ & $\begin{array}{c}12.45 \\
(46.82)\end{array}$ & $\begin{array}{c}11.00 \\
(54.23)\end{array}$ & $\begin{array}{c}9.36 \\
(55.59)\end{array}$ & $\begin{array}{c}13.31 \\
(29.48)\end{array}$ & $\begin{array}{c}13.44 \\
(38.96)\end{array}$ & $\begin{array}{c}9.92 \\
(32.22)\end{array}$ & $\begin{array}{c}9.51 \\
(25.39)\end{array}$ & $\begin{array}{c}8.11 \\
(31.76)\end{array}$ & $\begin{array}{c}6.12 \\
(25.65)\end{array}$ \\
\hline \multicolumn{16}{|c|}{ College } \\
\hline Child Penalty & 56.61 & 42.31 & 38.62 & 60.25 & 45.11 & 41.55 & 18.49 & 15.13 & 16.63 & 39.20 & 35.16 & 32.04 & 33.47 & 22.11 & 24.42 \\
\hline $\begin{array}{l}\text { Extensive Margin } \\
\% \text { Explained }\end{array}$ & $\begin{array}{c}35.05 \\
(61.92)\end{array}$ & $\begin{array}{c}22.40 \\
(52.94)\end{array}$ & $\begin{array}{c}22.11 \\
(57.24)\end{array}$ & $\begin{array}{c}37.06 \\
(61.52)\end{array}$ & $\begin{array}{c}23.53 \\
(52.16)\end{array}$ & $\begin{array}{c}23.60 \\
(56.78)\end{array}$ & $\begin{array}{c}7.45 \\
(40.29)\end{array}$ & $\begin{array}{c}6.65 \\
(43.96)\end{array}$ & $\begin{array}{c}7.39 \\
(44.42)\end{array}$ & $\begin{array}{c}26.18 \\
(66.79)\end{array}$ & $\begin{array}{c}21.65 \\
(61.59)\end{array}$ & $\begin{array}{c}20.44 \\
(63.80)\end{array}$ & $\begin{array}{c}26.85 \\
(80.22)\end{array}$ & $\begin{array}{c}17.94 \\
(81.16)\end{array}$ & $\begin{array}{c}18.11 \\
(74.15)\end{array}$ \\
\hline $\begin{array}{l}\text { Intensive Margin } \\
\text { \% Explained }\end{array}$ & $\begin{array}{c}21.56 \\
(38.08)\end{array}$ & $\begin{array}{c}19.91 \\
(47.06)\end{array}$ & $\begin{array}{c}16.51 \\
(42.76)\end{array}$ & $\begin{array}{c}23.19 \\
(38.48)\end{array}$ & $\begin{array}{c}21.58 \\
(47.84)\end{array}$ & $\begin{array}{c}17.96 \\
(43.22)\end{array}$ & $\begin{array}{c}11.04 \\
(59.71)\end{array}$ & $\begin{array}{c}8.48 \\
(56.04)\end{array}$ & $\begin{array}{c}9.24 \\
(55.58)\end{array}$ & $\begin{array}{c}13.02 \\
(33.21)\end{array}$ & $\begin{array}{c}13.50 \\
(38.41)\end{array}$ & $\begin{array}{c}11.60 \\
(36.20)\end{array}$ & $\begin{array}{c}6.62 \\
(19.78)\end{array}$ & $\begin{array}{c}4.17 \\
(18.84)\end{array}$ & $\begin{array}{c}6.31 \\
(25.85)\end{array}$ \\
\hline
\end{tabular}

Source: U.S. Census (IPUMS). All observations with flagged values on any of the variables of interest are dropped from the analysis. Sampling weights used.

Numbers do not always add up due to rounding. 
Table 3. Decomposition of the Child Penalty in Unconditional Annual Hours by Year (Non-Hispanic White College Educated Married Women)

\begin{tabular}{|c|c|c|c|c|c|c|c|c|c|c|c|c|}
\hline & $\begin{array}{l}1980 \\
(1)\end{array}$ & $\begin{array}{l}1981-1983 \\
\text { (2) }\end{array}$ & $\begin{array}{l}\text { 1984-1986 } \\
\text { (3) }\end{array}$ & $\begin{array}{l}1987-1989 \\
\text { (4) }\end{array}$ & $\begin{array}{l}1990 \\
(5)\end{array}$ & $\begin{array}{l}1991-1993 \\
\text { (6) }\end{array}$ & $\begin{array}{l}\text { 1994-1996 } \\
\text { (7) }\end{array}$ & $\begin{array}{c}1997-1999 \\
(8)\end{array}$ & $\begin{array}{l}2000 \\
(9)\end{array}$ & $\begin{array}{l}\text { 2001-2003 } \\
\quad(10)\end{array}$ & $\begin{array}{l}2004-2006 \\
\quad(11)\end{array}$ & $\begin{array}{l}2007-2009 \\
\quad(12)\end{array}$ \\
\hline Child & 60 & 55.09 & 48.23 & 46.66 & 45.11 & 41.44 & 40.03 & 40.17 & 41.55 & 42.22 & 39.90 & 38.31 \\
\hline $\begin{array}{l}\text { Extensive Margin } \\
\% \text { Explained }\end{array}$ & $\begin{array}{c}37.06 \\
(61.52)\end{array}$ & $\begin{array}{c}30.07 \\
(54.59)\end{array}$ & $\begin{array}{c}25.95 \\
(53.81)\end{array}$ & $\begin{array}{c}24.56 \\
(52.65)\end{array}$ & $\begin{array}{c}23.53 \\
(52.16)\end{array}$ & $\begin{array}{c}20.66 \\
(49.84)\end{array}$ & $\begin{array}{c}19.98 \\
(49.90)\end{array}$ & $\begin{array}{c}20.13 \\
(50.12)\end{array}$ & $\begin{array}{c}23.60 \\
(56.78)\end{array}$ & $\begin{array}{c}23.46 \\
(55.57)\end{array}$ & $\begin{array}{c}22.56 \\
(56.54)\end{array}$ & $\begin{array}{c}21.09 \\
(55.04)\end{array}$ \\
\hline $\begin{array}{l}\text { Intensive Margin } \\
\% \text { Explained }\end{array}$ & $\begin{array}{c}23.19 \\
(38.48)\end{array}$ & $\begin{array}{c}25.02 \\
(45.41)\end{array}$ & $\begin{array}{c}22.27 \\
(46.19)\end{array}$ & $\begin{array}{c}22.09 \\
(47.35)\end{array}$ & $\begin{array}{c}21.58 \\
(47.84)\end{array}$ & $\begin{array}{c}20.78 \\
(50.16)\end{array}$ & $\begin{array}{c}20.05 \\
(50.10)\end{array}$ & $\begin{array}{c}20.04 \\
(49.88)\end{array}$ & $\begin{array}{c}17.96 \\
(43.22)\end{array}$ & $\begin{array}{c}18.75 \\
(44.43)\end{array}$ & $\begin{array}{c}17.34 \\
(43.46)\end{array}$ & $\begin{array}{c}17.22 \\
(44.96)\end{array}$ \\
\hline
\end{tabular}

Source: U.S. Census (IPUMS) in yellow and the March Current Population Survey (IPUMS). All observations with flagged values on any of the variables of interest are dropped from the analysis. Sampling weights used. Numbers do not always add up due to rounding. 
Table 4. Decomposition of the Child Penalty in Unconditional Annual Hours by Year and Age (Non-Hispanic White College Educated Married Women)

\begin{tabular}{|c|c|c|c|c|c|c|c|c|c|c|c|c|c|c|c|}
\hline & \multicolumn{3}{|c|}{ Total } & \multicolumn{3}{|c|}{$25-29$} & \multicolumn{3}{|c|}{$30-34$} & \multicolumn{3}{|c|}{$35-39$} & \multicolumn{3}{|c|}{$40-44$} \\
\hline & $\begin{array}{l}1980 \\
(1)\end{array}$ & $\begin{array}{l}1990 \\
(2)\end{array}$ & $\begin{array}{c}2000 \\
(3)\end{array}$ & $\begin{array}{c}1980 \\
(4)\end{array}$ & $\begin{array}{l}1990 \\
(5)\end{array}$ & $\begin{array}{c}2000 \\
(6)\end{array}$ & $\begin{array}{l}1980 \\
(7)\end{array}$ & $\begin{array}{c}1990 \\
(8)\end{array}$ & $\begin{array}{c}2000 \\
(9)\end{array}$ & $\begin{array}{l}1980 \\
(10)\end{array}$ & $\begin{array}{l}1990 \\
(11)\end{array}$ & $\begin{array}{l}2000 \\
(12)\end{array}$ & $\begin{array}{l}1980 \\
(13)\end{array}$ & $\begin{array}{l}1990 \\
(14)\end{array}$ & $\begin{array}{l}2000 \\
(15)\end{array}$ \\
\hline \multicolumn{16}{|l|}{ Total } \\
\hline Child Penalty & 60.25 & 45.11 & 41.55 & 54.46 & 38.85 & 34.12 & 62.47 & 46.14 & 42.77 & 64.20 & 48.33 & 45.47 & 59.95 & 44.29 & 41.89 \\
\hline $\begin{array}{l}\text { Extensive Margin } \\
\text { \% Explained }\end{array}$ & $\begin{array}{c}37.06 \\
(61.52)\end{array}$ & $\begin{array}{c}23.53 \\
(52.16)\end{array}$ & $\begin{array}{c}23.60 \\
(56.78)\end{array}$ & $\begin{array}{c}29.50 \\
(54.16)\end{array}$ & $\begin{array}{c}16.97 \\
(43.68)\end{array}$ & $\begin{array}{c}16.01 \\
(46.91)\end{array}$ & $\begin{array}{c}39.23 \\
(62.81)\end{array}$ & $\begin{array}{c}23.73 \\
(51.43)\end{array}$ & $\begin{array}{c}23.25 \\
(54.35)\end{array}$ & $\begin{array}{c}43.46 \\
(67.70)\end{array}$ & $\begin{array}{c}26.50 \\
(54.84)\end{array}$ & $\begin{array}{c}26.96 \\
(59.29)\end{array}$ & $\begin{array}{c}41.00 \\
(68.39)\end{array}$ & $\begin{array}{c}25.85 \\
(58.37)\end{array}$ & $\begin{array}{c}24.90 \\
(59.44)\end{array}$ \\
\hline $\begin{array}{l}\text { Intensive Margin } \\
\text { \% Explained }\end{array}$ & $\begin{array}{c}23.19 \\
(38.48)\end{array}$ & $\begin{array}{c}21.58 \\
(47.84)\end{array}$ & $\begin{array}{c}17.96 \\
(43.22)\end{array}$ & $\begin{array}{c}24.96 \\
(45.84)\end{array}$ & $\begin{array}{c}21.88 \\
(56.32)\end{array}$ & $\begin{array}{c}18.12 \\
(53.09)\end{array}$ & $\begin{array}{c}23.23 \\
(37.19)\end{array}$ & $\begin{array}{c}22.41 \\
(48.57)\end{array}$ & $\begin{array}{c}19.53 \\
(45.65)\end{array}$ & $\begin{array}{c}20.74 \\
(32.30)\end{array}$ & $\begin{array}{c}21.83 \\
(45.16)\end{array}$ & $\begin{array}{c}18.51 \\
(40.71)\end{array}$ & $\begin{array}{c}18.95 \\
(31.61)\end{array}$ & $\begin{array}{c}18.44 \\
(41.63)\end{array}$ & $\begin{array}{c}16.99 \\
(40.56)\end{array}$ \\
\hline
\end{tabular}

Source: U.S. Census (IPUMS). All observations with flagged values on any of the variables of interest are dropped from the analysis. Sampling weights used.

Numbers do not always add up due to rounding. 
Table 5. Decomposition of the Child Penalty in Unconditional Annual Hours by Year and Occupation (Non-Hispanic White College Educated Married Women)

\begin{tabular}{|c|c|c|c|c|c|c|c|c|c|c|c|c|c|c|c|}
\hline & $\begin{array}{l}\text { Manage } \\
1980\end{array}$ & $\begin{array}{c}\text { erial/Profe } \\
1990\end{array}$ & $\begin{array}{c}\text { essional } \\
2000\end{array}$ & & & & & & & & & & & & \\
\hline Child Penalty & 49.19 & 36.29 & 32.05 & & & & & & & & & & & & \\
\hline Extensive Margin & 21.89 & 13.02 & 12.39 & & & & & & & & & & & & \\
\hline \% Explained & $(44.50)$ & (35.89) & $(38.67)$ & & & & & & & & & & & & \\
\hline Intensive Margin & 27.30 & 23.27 & 19.65 & & & & & & & & & & & & \\
\hline \% Explained & $(55.50)$ & $(64.11)$ & $(61.33)$ & & & & & & & & & & & & \\
\hline \multicolumn{16}{|c|}{ Traditionally Male Dominated Occupations } \\
\hline & \multicolumn{3}{|c|}{ Architects } & \multicolumn{3}{|c|}{ Electrical Engineers } & \multicolumn{3}{|c|}{ Physicians } & \multicolumn{3}{|c|}{ Lawyers } & \multicolumn{3}{|c|}{ Clergy/Religious Workers } \\
\hline & 1980 & 1990 & 2000 & 1980 & 1990 & 2000 & 1980 & 1990 & 2000 & 1980 & 1990 & 2000 & 1980 & 1990 & 2000 \\
\hline Child Penalty & 51.44 & 35.16 & 39.51 & 27.25 & 25.66 & 27.20 & 28.46 & 19.88 & 23.81 & 24.02 & 24.53 & 26.97 & 46.99 & 47.77 & 43.24 \\
\hline Extensive Margin & 10.60 & 9.35 & 15.12 & 25.12 & 9.05 & 14.11 & 6.27 & 3.24 & 2.22 & 8.10 & 8.89 & 7.97 & 18.94 & 14.33 & 9.66 \\
\hline \% Explained & (20.61) & (26.58) & (38.26) & $(92.20)$ & (35.25) & (51.85) & (22.03) & $(16.28)$ & $(9.32)$ & (33.73) & (36.23) & (29.57) & $(40.30)$ & (29.99) & (22.34) \\
\hline Intensive Margin & 40.84 & 25.82 & 24.39 & 2.13 & 16.62 & 13.10 & 22.19 & 16.64 & 21.59 & 15.92 & 15.64 & 18.99 & 28.05 & 33.45 & 33.58 \\
\hline \% Explained & (79.39) & (73.42) & $(61.74)$ & $(7.80)$ & $(64.75)$ & $(48.15)$ & (77.97) & $(83.72)$ & (90.68) & $(66.27)$ & (63.77) & $(70.43)$ & (59.70) & $(70.01)$ & (77.66) \\
\hline \multicolumn{16}{|c|}{ Traditionally Female Dominated Occupations } \\
\hline & \multicolumn{3}{|c|}{ Registered Nurses } & \multicolumn{3}{|c|}{ Dieticians/Nutrionists } & \multicolumn{3}{|c|}{ Occupational Therapists } & \multicolumn{3}{|c|}{ Primary School Teachers } & \multicolumn{3}{|c|}{ Librarians } \\
\hline & 1980 & 1990 & 2000 & 1980 & 1990 & 2000 & 1980 & 1990 & 2000 & 1980 & 1990 & 2000 & 1980 & 1990 & 2000 \\
\hline Child Penalty & 49.97 & 38.05 & 32.99 & 48.69 & 38.44 & 40.63 & 49.75 & 38.38 & 33.53 & 48.33 & 32.26 & 28.94 & 49.48 & 36.48 & 34.67 \\
\hline Extensive Margin & 16.40 & 9.30 & 9.56 & 19.92 & 9.56 & 13.43 & 20.40 & 6.68 & 8.04 & 25.65 & 14.08 & 14.16 & 25.93 & 16.59 & 14.78 \\
\hline \% Explained & (32.81) & $(24.43)$ & (28.97) & $(40.90)$ & $(24.86)$ & (33.06) & $(41.01)$ & $(17.40)$ & (23.99) & (53.08) & (43.64) & $(48.92)$ & $(52.40)$ & $(45.46)$ & (42.63) \\
\hline Intensive Margin & 33.57 & 28.76 & 23.44 & 28.78 & 28.89 & 27.20 & 29.35 & 31.70 & 25.48 & 22.68 & 18.18 & 14.78 & 23.55 & 19.89 & 19.89 \\
\hline \% Explained & (67.19) & $(75.57)$ & (71.03) & (59.10) & (75.14) & $(66.94)$ & (58.99) & $(82.60)$ & $(76.01)$ & $(46.92)$ & $(56.36)$ & (51.08) & $(47.60)$ & $(54.54)$ & (57.37) \\
\hline \multicolumn{16}{|c|}{ Mixed Occupations } \\
\hline & \multicolumn{3}{|c|}{ Human Resources } & \multicolumn{3}{|c|}{ Accountants/Auditors } & \multicolumn{3}{|c|}{ Secondary School Teachers } & \multicolumn{3}{|c|}{ Economists } & \multicolumn{3}{|c|}{ Editors/Reporters } \\
\hline & 1980 & 1990 & 2000 & 1980 & 1990 & 2000 & 1980 & 1990 & 2000 & 1980 & 1990 & 2000 & 1980 & 1990 & 2000 \\
\hline Child Penalty & 38.57 & 30.46 & 26.37 & 43.03 & 35.09 & 33.31 & 45.49 & 31.72 & 29.61 & 41.18 & 38.93 & 28.85 & 56.35 & 42.27 & 40.89 \\
\hline Extensive Margin & 29.02 & 17.29 & 14.35 & 23.05 & 15.04 & 13.00 & 21.67 & 13.82 & 11.80 & 23.30 & 21.31 & 10.81 & 23.28 & 13.70 & 12.69 \\
\hline \% Explained & $(75.22)$ & $(56.77)$ & $(54.42)$ & (53.55) & $(42.86)$ & (39.02) & $(47.65)$ & $(43.56)$ & (39.83) & (56.58) & $(54.75)$ & $(37.45)$ & $(41.31)$ & $(32.42)$ & (31.04) \\
\hline Intensive Margin & 9.56 & 13.17 & 12.02 & 19.99 & 20.05 & 20.31 & 23.81 & 17.90 & 17.82 & 17.88 & 17.62 & 18.05 & 33.07 & 28.57 & 28.20 \\
\hline \% Explained & $(24.78)$ & (43.23) & (45.58) & $(46.45)$ & $(57.14)$ & $(60.98)$ & $(52.35)$ & $(56.44)$ & $(60.17)$ & $(43.42)$ & $(45.25)$ & $(62.55)$ & (58.69) & $(67.58)$ & (68.96) \\
\hline
\end{tabular}

Source: U.S. Census (IPUMS). All observations with flagged values on any of the variables of interest are dropped from the analysis. Sampling weights used.

Numbers do not always add up due to rounding.

See Appendix Table 2 for percent male in the occupation and sample sizes. 
Appendix Table 1. Variable Definitions

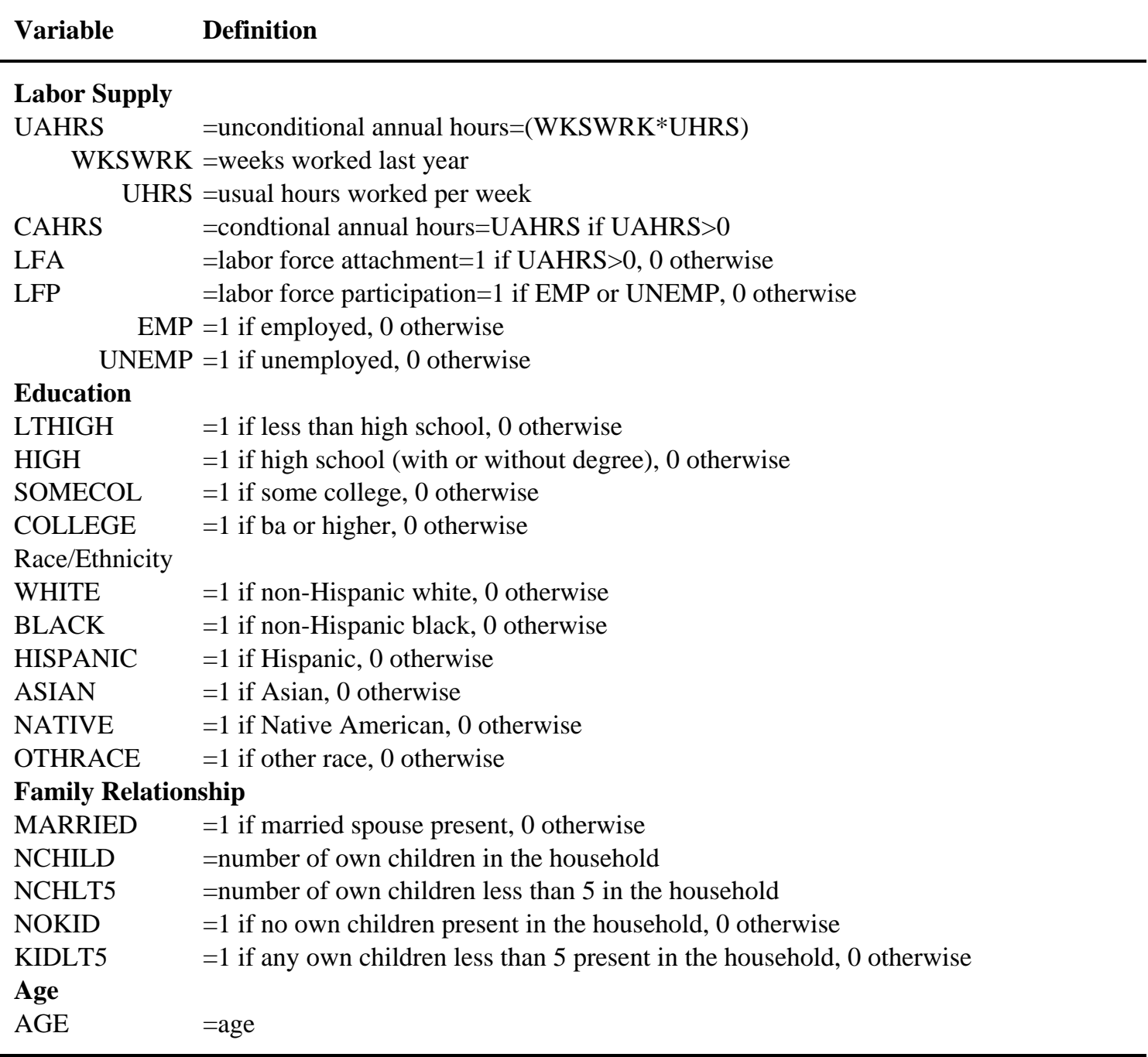




\begin{tabular}{|c|c|c|c|c|c|c|c|c|c|}
\hline & \%Male & $\begin{array}{c}1980 \\
\text { N (No Kids) }\end{array}$ & N (Kids lt5) & \%Male & $\begin{array}{c}1990 \\
\text { N (No Kids) }\end{array}$ & N (Kids lt5) & \%Male & $\begin{array}{c}2000 \\
\text { N (No Kids) }\end{array}$ & N (Kids lt5) \\
\hline \multicolumn{10}{|l|}{ Male Dominated Occupations } \\
\hline Chief executives and public administrat & 0.747 & 14 & 8 & 0.703 & 4 & 5 & 0.800 & 381 & 487 \\
\hline Funeral directors & 0.912 & 3 & 2 & 0.864 & 6 & 4 & 0.819 & 7 & 10 \\
\hline Purchasing agents and buyers, of farm p & 0.904 & 0 & 2 & 0.799 & 2 & 2 & 0.754 & 4 & 2 \\
\hline Construction inspectors & 0.948 & 1 & 0 & 0.929 & 3 & 7 & 0.890 & 3 & 5 \\
\hline Architects & 0.905 & 64 & 25 & 0.835 & 155 & 169 & 0.778 & 178 & 183 \\
\hline Aerospace engineer & 0.966 & 10 & 0 & 0.913 & 76 & 52 & 0.904 & 34 & 64 \\
\hline Metallurgical and materials engineers, & 0.947 & 8 & 1 & 0.865 & 9 & 14 & 0.886 & 16 & 10 \\
\hline Petroleum, mining, and geological engin & 0.954 & 2 & 1 & 0.934 & 11 & 11 & 0.928 & 7 & 11 \\
\hline Chemical engineers & 0.946 & 12 & 6 & 0.882 & 50 & 32 & 0.845 & 52 & 64 \\
\hline Civil engineers & 0.966 & 26 & 12 & 0.926 & 90 & 96 & 0.888 & 132 & 137 \\
\hline Electrical engineer & 0.947 & 52 & 25 & 0.899 & 238 & 179 & 0.892 & 115 & 114 \\
\hline Industrial engineers & 0.898 & 44 & 13 & 0.853 & 84 & 77 & 0.825 & 122 & 135 \\
\hline Mechanical engineers & 0.976 & 14 & 4 & 0.945 & 48 & 51 & 0.932 & 75 & 91 \\
\hline Not-elsewhere-classified engineers & 0.957 & 34 & 25 & 0.896 & 221 & 174 & 0.880 & 178 & 179 \\
\hline Physicists and astronomers & 0.940 & 7 & 4 & 0.852 & 18 & 13 & 0.860 & 10 & 10 \\
\hline Atmospheric and space scientists & 0.858 & 1 & 3 & 0.877 & 7 & 1 & 0.878 & 10 & 5 \\
\hline Geologists & 0.871 & 35 & 10 & 0.834 & 79 & 53 & 0.742 & 133 & 111 \\
\hline Agricultural and food scientists & 0.752 & 17 & 10 & 0.707 & 35 & 42 & 0.726 & 33 & 34 \\
\hline Foresters and conservation scientists & 0.877 & 16 & 8 & 0.852 & 36 & 20 & 0.841 & 36 & 33 \\
\hline Physicians & 0.849 & 257 & 207 & 0.778 & 562 & 853 & 0.715 & 629 & 1142 \\
\hline Dentists & 0.918 & 30 & 23 & 0.857 & 108 & 170 & 0.802 & 95 & 159 \\
\hline Optometrists & 0.902 & 9 & 3 & 0.821 & 33 & 44 & 0.693 & 52 & 77 \\
\hline Podiatrists & 0.909 & 0 & 2 & 0.891 & 5 & 5 & 0.821 & 10 & 17 \\
\hline Clergy and religious workers & 0.851 & 78 & 138 & 0.766 & 153 & 63 & 0.702 & 214 & 361 \\
\hline Lawyers & 0.844 & 542 & 262 & 0.734 & 1310 & 1333 & 0.682 & 1350 & 1728 \\
\hline Announcers & 0.790 & 16 & 7 & 0.780 & 24 & 29 & 0.764 & 16 & 14 \\
\hline
\end{tabular}




\begin{tabular}{|c|c|c|c|c|c|c|c|c|c|}
\hline & \%Male & $\begin{array}{c}1980 \\
\text { N (No Kids) }\end{array}$ & N (Kids lt5) & \%Male & $\begin{array}{c}1990 \\
\text { N (No Kids) }\end{array}$ & N (Kids lt5) & \%Male & $\begin{array}{c}2000 \\
\text { N (No Kids) }\end{array}$ & N (Kids lt5) \\
\hline \multicolumn{10}{|l|}{ Female Dominated Occupations } \\
\hline Registered nurses & 0.039 & 2027 & 2853 & 0.054 & 3099 & 6284 & 0.074 & 2835 & 5784 \\
\hline Dietitians and nutritionists & 0.096 & 183 & 180 & 0.099 & 225 & 417 & 0.094 & 211 & 350 \\
\hline Occupational therapists & 0.073 & 106 & 94 & 0.113 & 206 & 329 & 0.096 & 313 & 495 \\
\hline Physical therapists & 0.257 & 186 & 185 & 0.236 & 342 & 507 & 0.269 & 520 & 830 \\
\hline Speech therapists & 0.099 & 329 & 386 & 0.072 & 382 & 710 & 0.069 & 512 & 722 \\
\hline Therapists, n.e.c. & 0.299 & 106 & 86 & 0.259 & 214 & 239 & 0.238 & 264 & 270 \\
\hline Kindergarten and earlier school teacher & 0.031 & 410 & 1058 & 0.019 & 254 & 1037 & 0.019 & 508 & 1257 \\
\hline Primary school teachers & 0.219 & 8251 & 12576 & 0.204 & 6989 & 11640 & 0.200 & 6993 & 11536 \\
\hline Special education teachers & 0.300 & 89 & 85 & 0.163 & 164 & 314 & 0.128 & 522 & 688 \\
\hline Librarians & 0.167 & 533 & 401 & 0.196 & 382 & 403 & 0.176 & 256 & 242 \\
\hline Dancers & 0.218 & 10 & 4 & 0.212 & 16 & 17 & 0.130 & 8 & 11 \\
\hline \multicolumn{10}{|l|}{ Mixed Occupations } \\
\hline Legislators & 0.614 & 5 & 11 & 0.573 & 14 & 10 & 0.555 & 12 & 8 \\
\hline Human resources and labor relations man & 0.615 & 184 & 94 & 0.493 & 365 & 267 & 0.432 & 540 & 607 \\
\hline Managers in education and related field & 0.596 & 422 & 308 & 0.466 & 726 & 813 & 0.384 & 675 & 844 \\
\hline Postmasters and mail superintendents & 0.572 & 1 & 2 & 0.540 & 4 & 11 & 0.445 & 6 & 7 \\
\hline Managers of properties and real estate & 0.550 & 43 & 56 & 0.507 & 197 & 209 & 0.454 & 181 & 235 \\
\hline Accountants and auditors & 0.588 & 894 & 537 & 0.453 & 2768 & 2752 & 0.405 & 2688 & 3967 \\
\hline Other financial specialists & 0.516 & 313 & 210 & 0.461 & 739 & 742 & 0.489 & 734 & 899 \\
\hline Personnel, HR, training, and labor rela & 0.504 & 491 & 275 & 0.416 & 757 & 662 & 0.325 & 1419 & 1450 \\
\hline Buyers, wholesale and retail trade & 0.517 & 158 & 71 & 0.439 & 207 & 197 & 0.434 & 185 & 224 \\
\hline Medical scientists & 0.579 & 32 & 28 & 0.558 & 75 & 68 & 0.524 & 119 & 103 \\
\hline Subject instructors (HS/college) & 0.590 & 878 & 1156 & 0.559 & 1023 & 1237 & 0.510 & 1460 & 1684 \\
\hline Secondary school teachers & 0.405 & 2586 & 3380 & 0.414 & 1386 & 1907 & 0.396 & 1462 & 1975 \\
\hline Archivists and curators & 0.504 & 41 & 12 & 0.440 & 69 & 44 & 0.411 & 69 & 62 \\
\hline Economists, market researchers, and sur & 0.691 & 151 & 75 & 0.549 & 376 & 289 & 0.513 & 203 & 238 \\
\hline Social scientists, n.e.c. & 0.576 & 26 & 16 & 0.518 & 44 & 41 & 0.485 & 72 & 51 \\
\hline Writers and authors & 0.507 & 79 & 77 & 0.480 & 200 & 281 & 0.439 & 247 & 405 \\
\hline Designers & 0.453 & 380 & 296 & 0.408 & 817 & 831 & 0.416 & 968 & 1078 \\
\hline Art makers: painters, sculptors, craft- & 0.484 & 223 & 159 & 0.446 & 308 & 77 & 0.505 & 258 & 220 \\
\hline Editors and reporters & 0.477 & 429 & 306 & 0.467 & 576 & 554 & 0.489 & 506 & 487 \\
\hline
\end{tabular}

Source: U.S. Census (IPUMS). All observations with flagged values on any of the variables of interest are dropped from the analysis. Sampling weights used.

Notes: \% Male is the percent of the occupation that is male for all individuals between the ages of 18-64. N (No Kids) and N(Kids lt5) are the sample sizes for college educated Non-Hispanic white married women between the ages of 25-44 without and with kids less than 5, respectively. 
Appendix Table 3. Decomposition of the Child Penalty in Unconditional Annual Hours by Birth Cohort and Age

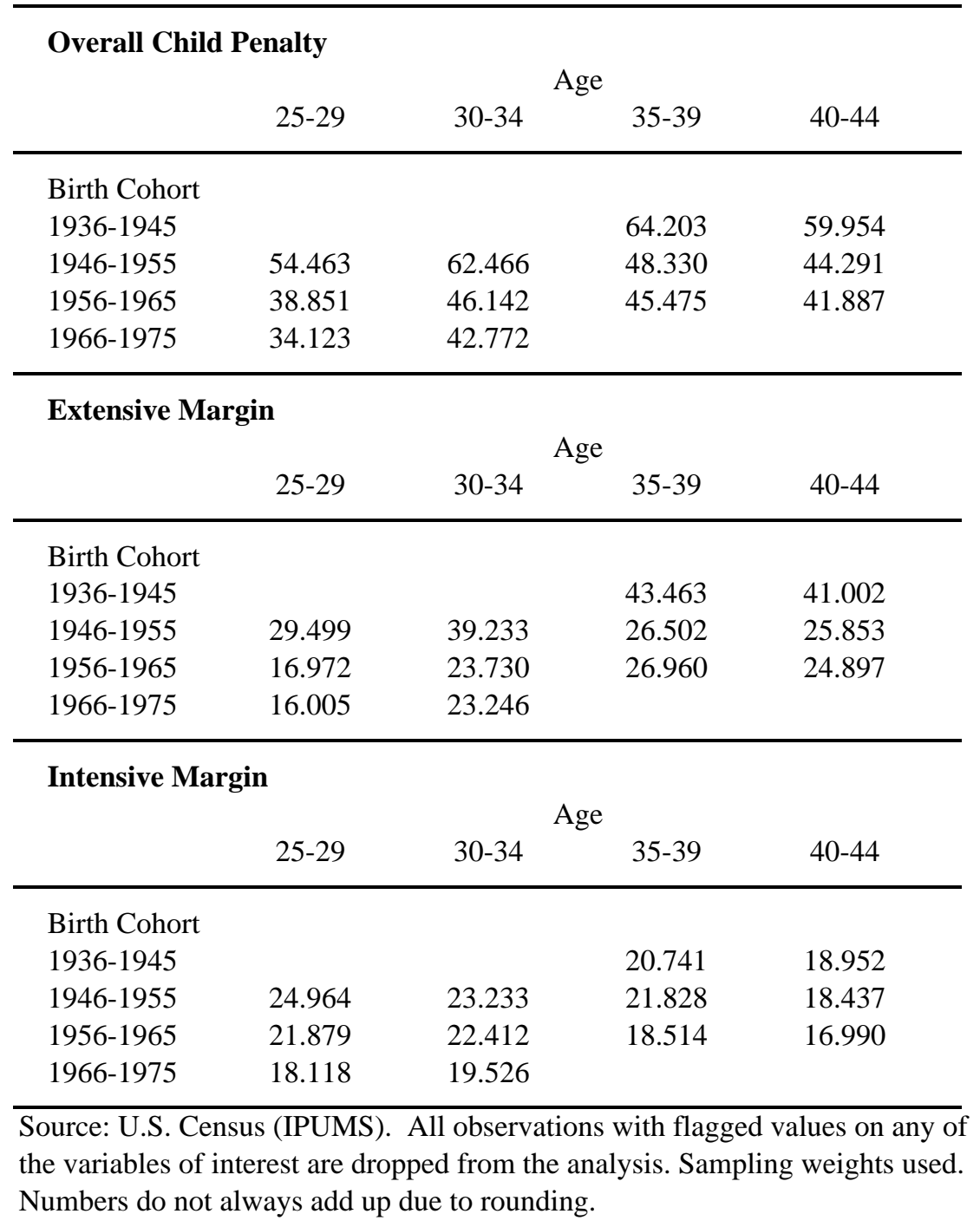

